\title{
The embryonic stress response to in vitro culture: insight from genomic analysis
}

\author{
Gael Cagnone and Marc-André Sirard \\ Département des Sciences Animales Pavillon des services, Université Laval, Quebec, QC, Canada \\ Correspondence should be addressed to G Cagnone; Email: gael.cagnone.1@gmail.com
}

\begin{abstract}
Recent genomic studies have shed light on the impact of in vitro culture (IVC) on embryonic homeostasis and the differential gene expression profiles associated with lower developmental competence. Consistently, the embryonic stress responses to IVC conditions correlate with transcriptomic changes in pathways related to energetic metabolism, extracellular matrix remodelling and inflammatory signalling. These changes appear to result from a developmental adaptation that enhances a Warburg-like effect known to occur naturally during blastulation. First discovered in cancer cells, the Warburg effect (increased glycolysis under aerobic conditions) is thought to result from mitochondrial dysfunction. In the case of IVC embryos, culture conditions may interfere with mitochondrial maturation and oxidative phosphorylation, forcing cells to rely on glycolysis in order to maintain energetic homeostasis. While beneficial in the short term, such adaptations may lead to epigenetic changes with potential long-term effects on implantation, foetal growth and post-natal health. We conclude that lessening the detrimental effects of IVC on mitochondrial activity would lead to significantly improved embryo quality.

Reproduction (2016) 152 R247-R261
\end{abstract}

\section{The purpose of studying embryogenomics in the assisted reproduction context}

Embryo culture is an essential aspect of assisted reproductive technology since its purpose is to allow the zygote to grow, divide and reach a stage at which it can be transferred to the uterus. The first media formulated for in vitro culture (IVC) of mammalian embryos were quite unreliable, often causing early development to stall at the maternal-embryonic transition phase (Brinster 1963). Improvements in medium composition have largely overcome this problem (Brinster \& Troike 1979, Schini \& Bavister 1988) and commercially available culture media now support embryo development to the blastocyst stage in various species. The rise of assisted reproductive technologies (ART) is accountable for a growing portion of the livestock population. More than 5 million human beings are born due to ART since Louise Brown in 1978. This currently represents about $1-2 \%$ of births in developing countries.

Despite its widespread use, IVC continues to produce embryos of lower viability compared with natural conception (Nair 2008), making multiple/repetitive transfers necessary. Its impact on early development and hence on the quality of the transferred embryos remains considerable (Nelissen et al. 2012). On one hand, almost all ARTs use either superovulation or, in experimental procedures, abattoir-derived material, to obtain mature eggs for in vitro fertilisation. These eggs have usually lower quality compared with naturally ovulating eggs, which is a major determinant of fertilisation and developmental success. On the other hand, sub-optimal culture conditions also reduce embryonic quality due to improper homeostasis regulation during early development (Summers \& Biggers 2003). Moreover, the impact of IVC may be variable between embryos originating from in vitro or in vivo matured oocytes, inducing different stress responses that compromise the chances of successful implantation (Leese et al. 1998). Therefore, in vitro conditions could be optimised to reduce the impact of ART on embryo viability.

The first few cleavages after fertilisation take place under a regime of transcriptomic silence that persists until embryonic genome activation (EGA) is complete. During maturation, the gamete genomes therefore invested heavily in sustaining the first zygotic divisions and only the cytoplasmic compartment of the early embryo cells has any significant capacity to respond to stress. After EGA, the embryonic cells acquire a transcriptomic plasticity that provides certain responsiveness to external conditions (McKiernan \& Bavister 1994, van Soom et al. 1997). Moreover, the acquisition of gap junctions during compaction provides a better co-ordination between embryonic cells in terms of metabolism, signal transmission and response to the external conditions. Because early embryos behave as autonomous cells until EGA, this contributes to their heightened sensitivity to IVC-related stress compared with the later stages 
of preimplantation development (Brison et al. 2014). However, a considerable percentage of embryos still stall at the morula-to-blastocyst transition, and transcriptional state in blastocysts may remain compromised due to the adaptive response to the IVC environment (Summers \& Biggers 2003).

Total transcript amplification allows screening for several thousands of cDNA probes using only a few cells (Rizos et al. 2002b, Zheng et al. 2007, Smith et al. 2009, Seli et al. 2010). This approach has been used to assess the degree of modulation of the expression level of developmentally important genes in cultured embryos of different species (Khosla et al. 2001b, Lucifero et al. 2004). Although gene expression levels do not necessarily equate to functional effects in terms of active proteins, transcriptomic analyses have been valuable in picturing the global genomic impact underlying the embryonic response to different in vitro environments. Notably, during pre-implantation development of cattle embryos (in which EGA is late, as in human embryos), large numbers of genes are expressed at different levels depending on whether the embryos are produced in vivo (under optimal conditions in the oviduct) or in vitro (Wrenzycki et al. 1996, Niemann \& Wrenzycki 2000, Lazzari et al. 2002). The time-dependent sensitivity of early development to IVC is particularly apparent in cattle, in which transfer of embryos from the in vitro environment to the uterus is generally successful if timely (Gad et al. 2012). Using trophoblast biopsies before uterine transfer, a posteriori analysis of cases in which the recipient cow was not the oocyte donor has revealed IVC-specific differentially expressed genes (DEG) that are associated with gestational success or failure (El-Sayed et al. 2006, Ghanem et al. 2011).

Such breakthroughs have suggested that the measurement of transcriptomic perturbations could provide a diagnostic tool for assessing developmental competence (Lee et al. 2001, Jones et al. 2008). However, the importance of these perturbations for the quality of IVC embryos remains difficult to interpret in terms of direct links with the detrimental impact (stress) of the different culture components. In view of the considerable differences between in vitro and in vivo conditions, effects of IVC on embryonic gene expression patterns are to be expected. While there may be key DEGs that characterise inadequate stress responses indicating a detrimental impact on embryo quality, it cannot be ruled out that some and perhaps many DEGs represent developmental adaptations to IVC rather than damage to the embryo (Plourde et al. 2012).

\section{The embryonic responses to the IVC stress conditions}

Under IVC conditions, embryos are subjected to a variety of homeostatic pressures including physicochemical (temperature, osmolality and $\mathrm{pH}$ ), oxidative (pro-oxidant and anti-oxidant balance) and energetic (production, utilisation and storage) stresses, all of which can compromise further development (Summers \& Biggers 2003).

\section{Responses to physiochemical stress}

Very few studies have examined the effects of osmolality and $\mathrm{pH}$ on early embryo transcriptomes. It is nevertheless known that these parameters vary during IVC and deviate from the corresponding in vivo conditions. Embryos are able to tolerate a range of osmolalities although first studies showed that a reduced osmolality during IVC (around 270 mosmol) may enhance developmental rate (Brinster \& Troike 1979). However this is unlikely to be optimal, since in vivo data suggest osmolality of around 300 mosmol in the oviduct fluid. The hypertonic stress at physiological osmolality may be due to inappropriate concentrations of specific osmolytes in interaction with the salt level in the IVC medium (Richards et al. 2010, Baltz 2012). Osmolytes such as glycine and other amino acids become internalised through transporters and allow volume regulation during blastocyst expansion (Richards et al. 2010). More recent formulations of culture media therefore tend to include amino acids and organic osmolytes in order to increase osmolality to physiological levels, such as in oviduct fluid (Van Winkle \& Dickinson 1995, Baltz 2012). Some studies have focused on the impact of hypertonic stress on responses mediated by mitogen-activated protein kinase pathways such as p38 activation (Fong et al. 2007, Xie et al. 2007) or aquaporin expression/ localisation and apoptosis via MAPK14/11 and MAPK8 respectively (Bell et al. 2009). However, the extent to which the transcriptome responds to hypo-osmotic condition is still unclear.

The $\mathrm{pH}$ of a culture medium can increase quickly when the culture dish is handled outside of the incubator, but it can also change due to the metabolic activities of the embryo. Depending on the metabolic state of the cytoplasm (where glycolysis takes place) and the mitochondria, where oxidative phosphorylation (OXPHOS) takes place, ammonium ion can be liberated from amino acids, while lactate can be produced from pyruvate. Moreover, amino acids may spontaneously breakdown at $37^{\circ} \mathrm{C}$, releasing ammonium. The bicarbonate buffer used in culture media is likely sufficient to counteract $\mathrm{pH}$ variations in regard to the slow metabolism of early embryos. However, stressed embryos may release excessive amount of ammonium and lactate into the culture medium, which could decrease the local $\mathrm{pH}$ and, in turn, compromise embryo development (Dagilgan et al. 2014). More importantly, ammonium build-up in interaction with the oxygen level negatively impacts on the metabolism and gene expression during IVC 
of mouse embryos (Wale \& Gardner 2013a). Fluidic culture systems have been developed to renew the medium continually, while closed chamber systems now make it unnecessary to handle embryos outside of the incubator (Krisher \& Wheeler 2010). On this subject, detailed information on the effects of chemical and physical factors on mammalian embryo culture can been found in the review from Wales and Gardner (Wale \& Gardner 2015).

Temperature shifts experienced by embryos handled outside of the incubator may cause heat shock (Sakatani et al. 2012). The early stages of bovine preEGA embryo development are particularly sensitive to heat shock; this is associated with major changes in the transcriptomic profile at the morula stage (Sakatani et al. 2013). Responses to heat shock include the production of homeostatic regulators involved in the unfolding response via the ubiquitination pathway and the glutathione scavenging response to oxidative stress (Arechiga et al. 1995). These regulators consist of not only chaperone proteins (Edwards \& Hansen 1996) as well as apoptosis-related proteins such as Bax, Bid and Caspase-3 (Yadav et al. 2013) but also proteins associated with developmental competence genes, such as PLAC8 and CDX2 (Silva et al. 2013). A transcriptional dysregulation subject to wht signalling in conjunction with heparin sulphate proteoglycans also may result from HS exposure (Sakatani et al. 2013).

In cattle, the impact of heat shock can be lessened by IGF1 stimulation through MAPKK and PI3K (Jousan \& Hansen 2007), but this metabolic rescue is possible only when the shock occurs after EGA (Bonilla et al. 2011). Supplementation with free radical scavengers such as beta-mercaptoethanol has also been shown to decrease embryo mortality due to heat shock (Sakatani etal. 2008). In a mouse study, it was noted that expression of the X-linked gene for the metabolic enzyme G6PD was stronger in female embryos (Perez-Crespo et al. 2005), which would increase tolerance to heat-shockinduced free radicals during IVC. This indicates that the stress response during pre-implantation development results from the impact of heat shock on the metabolic state, which affects oxidative homeostasis and thus embryonic signalling.

\section{Response to oxidative stress}

Oxidative stress is the result of an imbalance between the production and elimination of reactive oxygen species (ROS). ROS of intracellular or extracellular origin include various free radicals such as superoxide anion, hydrogen peroxide, hydroxyl radical, hydroxyl ion and nitric oxide, which are formed during reactions that reduce oxygen (Agarwal et al. 2006). Oxidative stress can affect numerous physiological mechanisms and can be lethal to embryos (Yang et al. 1998, Betts \& Madan 2008). At low concentrations, ROS can activate cellular pathways that determine differentiation or proliferation, while higher concentrations appear to affect the integrity of cellular constituents such as lipids, proteins, amino acids and nucleic acids (Guerin et al. 2001). Early embryos produce ROS naturally even in the presence of low levels of oxygen, since they carry out OXPHOS as well as other redox reactions (Nasr-Esfahani \& Johnson 1991). However, several analyses have shown that one of the ways in which culture conditions are detrimental to embryo developmental competence is by increasing oxidative stress (Nasr-Esfahani et al. 1990, Nasr-Esfahani \& Johnson 1992).

Oxygen tension is an important regulator of oxidative metabolism (Wale \& Gardner 2013b, Wale \& Gardner 2015) and in vivo developing embryos are exposed to a lower oxygen concentration in the oviduct/uterus compared with the atmospheric condition (Khurana \& Niemann 2000). An atmosphere containing 5\% oxygen is recommended for human embryo culture (Gardner 2016), and numerous studies have shown the deleterious effects of oxygen at normal atmospheric concentrations (20-21\%) on embryo development and quality (Fujitani et al. 1997, Orsi \& Leese 2001, Balasubramanian et al. 2007). High oxygen tension increases $\mathrm{H}_{2} \mathrm{O}_{2}$ production, DNA fragmentation and apoptosis, and thereby decreases the percentage of IVC embryos reaching the blastocyst stage (Van Soom et al. 2002, Kitagawa et al. 2004). By affecting oxidative homeostasis, it might actually decrease energy production by the mitochondria (Harvey et al. 2004a). Uncouplers and inhibitors of OXPHOS appear to affect embryo development in a similar manner (Thompson et al. 2000, Machaty et al. 2001) as well as the expression of redox-sensitive genes such as HIF1A and HIF2A (Harvey et al. 2004b). Reduced oxygen tension increases the expression of metabolic genes involved in glycolysis such as LDHA (Harvey et al. 2007). Recent microarray analysis of human embryos has revealed the genome-wide impact of oxygen tension on gene expression related to metabolism, the cell cycle and OXPHOS (Mantikou et al. 2016).

Exogenous ROS will also stress the oxidative homeostasis of IVC embryos (Bedaiwy et al. 2004). Metal ions in the water, serum amine oxidase and visible light could contribute to increasing the concentration of ROS in a culture medium (Guerin et al. 2001, Wale \& Gardner 2015). The pro-oxidant factor 2,2'-azobis (2-amidinopropane) dihydrochloride (AAPH) is known to induce a self-perpetuating free radical formation that initiates cell membrane lipid peroxidation and generates ROS. Adding AAPH to the medium mimics the contribution of external ROS to developmental compromise during IVC and has been used to assess cellular responses (Feugang et al. 2003, 2005) and transcriptomic responses (Cagnone \& Sirard 2013) to oxidative stress in bovine embryos. 
Exogenous ROS (AAPH exposure) has a major impact on blastocyst integrity and activation of signalling pathways such as ERK $1 / 2$ as mechanisms of adaptation and survival. It also induces a rapid inflammatory response (TNF and IFN signalling), due possibly to lipid oxidation (Kim et al. 2010, Kopp et al. 2010). An inflammatory response during early development may further affect embryo competence (Van Sinderen et al. 2013). If this is true, cytokine release should be a useful marker of the oxidative stress experienced by IVC embryos before transfer (Johnson et al. 2003). Moreover, the use of antiinflammatory factors (such as pre-implantation factor) might improve the embryonic signalling in response to stress (Stamatkin et al. 2011), although it would not likely prevent internal ROS damage. For this purpose, a redox-balanced environment still needs to be designed, based perhaps on a cocktail of oxidative regulators and anti-oxidant molecules (Takahashi et al. 1993). However, while the role of factors such as glutathione in maintaining the oxidative balance in the oviduct has been brought to light (Salmen et al. 2005), researchers are still troubleshooting the optimal metabolic conditions for embryonic oxidative homeostasis (Truong et al. 2016).

Both the maternal environment and the embryo itself provide defences against ROS (glutathione, vitamins and albumin), and different enzymes such as glutathione peroxidase (GPX) or superoxide dismutase (SOD) are produced to eliminate excess ROS (Lequarre et al. 2001). Reduced glutathione $(\mathrm{GSH})$, synthesised primarily from cysteine, glutamate and glycine, plays a crucial role in scavenging hydrogen peroxide, an oxidative reaction catalysed by GPX. The enzyme GSH reductase ensures regeneration of GSH and thereby allows detoxification of the cell. This system is present in the oocyte and the embryo; GSH being stored during oocyte maturation is then utilised during pre-implantation development (Gardiner \& Reed 1994). This dynamic pattern reflects the change in oxidative metabolism from a quiescent state before EGA to an active state after EGA. We note with interest that increased GPX4 expression in response to oxidative stress has been observed in cattle blastocysts produced in vitro and that this transcriptomic response is correlated strongly with failure to bring about gestation (El-Sayed et al. 2006).

The sensitivity of cultured embryos to ROS may be due to impaired GSH turnover (Stover et al. 2000). Adding L-buthionine sulphoximine to the culture medium aggravates this deficiency by depleting the GSH reservoir in the embryo, thus causing a developmental blockage at the time of increased oxidative activity. Based on transcriptomic analysis of blastocysts, the resulting inflammatory response is clear (Cagnone \& Sirard 2013), although genes involved in glycine metabolism (a component of GSH) are also overexpressed. Embryos that survive this treatment also show decreased expression of genes associated with oxidative metabolism. Such a profile is typical in embryos produced in vivo and exhibiting a quiescent homeostasis, which might also be a marker of the best quality of blastocysts obtainable under conditions of extended culture. However, experimental validation is needed to ensure that conditions that select for this 'quiet' state do not do more harm than good.

\section{Response to energetic stress}

Accumulating of evidence shows that IVC embryos bear the hallmarks of energetic stress in terms of nutrient utilisation (increased conversion of glucose to lactate), nutrient storage (lipid accumulation) and ATP synthesis (Spielmann et al. 1984, Thompson et al. 1991, Van Blerkom et al. 1995, Khurana \& Niemann 2000, Swain et al. 2002, Romek et al. 2009). This metabolic state occurs because of inadequate support in the in vitro environment. Numerous attempts to replicate the conditions of the oviduct, including co-culturing embryos with feeder layers of somatic cells (Lee et al. 2001), have met with little success. As support for proper energy metabolism, in vitro conditions remain sub-optimal and require further improvement in order to lessen the energy stress response during IVC.

One of the first things understood about the impact of IVC on metabolism in embryos was that the glucose concentration used typically in culture media for somatic cells (around $5 \mathrm{mM}$ ) is deleterious for early embryos before MET, causing a Crabtree-like effect, that is, overstimulation of glycolysis, alteration of mitochondrial oxidative metabolism and increases in ROS production (Schini \& Bavister 1988, Seshagiri \& Bavister 1991, Leunda-Casi et al. 2002, Scott \& Whittingham 2002, Diaz-Ruiz et al. 2008). While in vivo glucose concentration is low in the oviduct, glucose concentration increases in the uterus in order to support the proliferative homeostasis of embryonic cells during compaction, blastulation and implantation. These findings were crucial to reformulating IVC medium composition (Downs \& Dow 1991, Fissore et al. 1992). Much lower glucose concentrations (around $0.2 \mathrm{mM}$ ) made it possible to overcome the developmental blockage at the MET in mouse embryos (Matsukawa et al. 2002). Afterwards, sequential media with increasing glucose concentrations were formulated in order to extend embryo culture until the blastocyst stage, thus selecting more competent embryos for transfer. However, the use of sequential media is arguably another stress since relocating suddenly the embryo from one media to another might have an impact on its homeostasis.

However, IVC embryos continue to suffer from energetic stress and around $50 \%$ of them go into developmental arrest before the blastocyst stage. To understand the molecular pathways associated with energetic stress, experimental models have been 
developed in which embryos must cope with maternal hyperglycaemia or with increased glucose concentration during IVC. In murine embryos, hyperglycaemia can induce DNA fragmentation and apoptosis through the expression of cell death effector pathways (Moley et al. 1998). In one study of cultured cattle embryos, increasing the glucose concentration from $0.2 \mathrm{mM}$ to $5 \mathrm{mM}$ during early cleavage stage had a significant impact on blastocyst development, metabolism and the transcriptome profile (Cagnone et al. 2012). Early exposure to high glucose concentrations decreased the ATP content during blastocyst expansion and induced premature changes in the expression of two transcription factors (hepatic nuclear factor 4 alpha and pleomorphic adenoma-gene-like 1; Gae L M Cagnone, Isabelle Dufort, Melanie L Sutton-McDowall, Hannah Brown, Jeremy G. Thompson and Marc-André Sirard, unpublished data) at the morula stage.

Like the response of somatic cells under conditions of diabetic hyperglycaemia (Pampfer et al. 1997, Pavlinkova et al. 2009), the transcriptomic response to high glucose in bovine blastocysts includes polyol pathway activation (to clear excess glucose) and affects the oxidative homeostasis (Morrison et al. 2004). Excess glucose also induces an inflammatory reaction, possibly because of increased advanced glycation end products (Haucke et al. 2014) and activation of hexosamine pathways, in particular O-linked glycosylation (Pantaleon et al. 2010, Pantaleon 2015, Wong et al. 2015). Other pathways that are activated include protein kinase $\mathrm{C}$ signalling and extracellular matrix remodelling into the fibrotic-like phenotype. According to the long-standing consensus, the polyol, advanced glycation end product, PKC and hexosamine pathways are activated due to increased mitochondrial ROS production, which inhibits GAPDH activity (Nishikawa et al. 2000). Such an effect has been observed in embryos from diabetic mothers (Wentzel et al. 2001, Wentzel et al. 2003) or cultured under stress created by high glucose concentrations (Karja et al. 2006), suggesting that energetic stress in pre-implantation embryos is a result of compromised OXPHOS (Moley et al. 1996, Chi et al. 2002, Mitchell et al. 2009).

Besides having an energetic deficiency, IVC embryos also differ from their in vivo counterparts in terms of lipid metabolism (Romek et al. 2009). Lipids are an important source of energy and anabolic products required for embryo development. The lipid droplets in the cells of an embryo are composed primarily of triglycerides and cholesterol esters. It is noteworthy that adding serum to the culture medium increases lipid accumulation in embryos (Rizos et al. 2003), which may affect their ability to survive cryopreservation (Rizos et al. 2002a). The low cryotolerance (Sudano et al. 2014) and cell degeneration (Huang et al. 2010) observed in these embryos correlate with differential expression of genes involved in lipid biosynthesis and cholesterol metabolism (Van Hoeck et al. 2015). Such effect could be due to any of the various factors present in serum (glucose, lipids, growth factors) (Leroy et al. 2010), and some studies have shown that the lipid fraction of serum increases the triglyceride and cholesterol contents of IVC embryos (Abe et al. 2002, Romek et al. 2009).

A recent analysis of bovine blastocysts produced in medium containing BSA plus the lipid fraction of serum revealed transcriptomic profiles exhibiting signs of lipid peroxidation and metabolic deregulation, in particular downregulation of LDLR, HMGCS1 and MSMO1, suggesting a stress response to accumulated cholesterol and inhibition of SREBP and PPAR signalling. Pathway analysis showed activation of the metabolic repressor NRIP1, which is involved in triglyceride utilisation and balance between energy storage and expenditure (Cagnone \& Sirard 2014). These findings are in agreement with those of Leroy et al. (2010) who showed the impact of IVC medium supplementation with high-fat and high-carbohydrate serum on early embryos (Leroy et al. 2010). This supplementation was associated with compromised blastocyst development and differential expression of genes involved in apoptosis, oxidative stress, metabolism and pluripotency. Finally, expression of ACAT2, a cytosolic acetoacetyl-CoA thiolase involved in mitochondrial utilisation of lipid and the synthesis of cholesterol in the placenta (Zolnierowicz et al. 1984), is regulated upwards in blastocysts that ultimately end up as miscarriages. This upregulation suggests impaired cholesterol metabolism, possibly in the mitochondria.

Supplementation of the medium with serum has been shown to accelerate development and increase the likelihood of blastocyst formation in cultured cattle embryos, but it also appears to increase the incidence of abnormal developments such as large offspring syndrome. In rodent studies, cultured blastocysts that developed faster had abnormal gene expression and imprinting patterns (Market Velker et al. 2012), while embryos developing in mothers fed a high-fat diet displayed compromised development (metabolic and inflammatory responses as well as mitochondrial stress) and long-term effects on offspring health (Shankar et al. 2011, Bermejo-Alvarez et al. 2012). These effects were enhanced when both parents were obese (Finger et al. 2015). The effect of the high-fat diet can be reversed by treating the mother with rosiglitazone (an agonist of PPAR gamma), which induces weight loss, improves oocyte quality and modifies the expression of PPAR target genes involved in cholesterol transport (Minge et al. 2008). Maternal exercise and diet management was also found to restore metabolic status in the embryos and the resulting foetuses (McPherson et al. 2013).

\section{Common transcriptomic manifestations of IVC stress in low-quality embryos}

The transcriptomes of pre-implantation IVC embryos tend to exhibit certain similarities that correlate with 
decreased embryonic quality compared with their in vivo counterparts. For bovine blastocysts, we have compiled microarray data from the EmbryoGENE transcriptomic platform, which allows highlighting several stress response markers in association with developmental competency after embryo transfer, as summarised in Supplementary Table 1, see section on Supplementary data at the end of the article. Based on differentially expressed genes between in vivo and in vitro produced blastocysts (Cagnone \& Sirard 2013), we can appreciate the correspondence with another study comparing transcriptomic profiles from embryos culture in vivo, in vitro or sequentially before and after EGA (Gad et al. 2012). In addition, we have overlaid the transcriptomic profile of biopsies from in vitro (El-Sayed et al. 2006) and in vivo (Ghanem et al. 2011) produced blastocysts failing to result in calf delivery (i.e. compared with those resulting in calf delivery). Finally, we show how DEGs in IVC blastocysts reflect the response to different stress conditions of culture (Cagnone et al. 2012, Cagnone \& Sirard 2013, 2014). Data from mouse (Heras et al. 2016) and human (Highet et al. 2015, Kleijkers et al. 2015) studies using different transcriptomic platforms are also provided. The transcriptomic biomarkers associated with compromised preimplantation development after IVC are involved in important biological functions such as metabolic homeostasis, extracellular matrix remodelling, inflammation and signal transduction.

\section{Metabolic stress response}

A large number of DEGs found in IVC embryos are associated with the metabolic stress response that involves the glucose (TPI1 and PGK1), lipid (LDLR and ACAT2), oxidative (GPX4, GPX8 and OLR1) and ion metabolism (S100A10, S100A14, KCNIP4, FTH1 and CLIC1). Although the molecular consequences of their differential expression during pre-implantation development remain to be defined, impaired glucose and lipid metabolism are known to compromise development. Signs of free radical damage such as lipid peroxidation are clearly associated with embryonic degeneration. Finally, changes affecting the metabolism of calcium and other ions are also correlated with disruptions of cell function that further compromise embryo viability (Im et al. 2007, Wang et al. 2013a). Culture conditions need to be optimised in order to lessen such detrimental metabolic responses, and here we indicate potential markers of the biological pathways involved in determining the impact of culture conditions on embryo quality.

\section{Extracellular matrix synthesis and remodelling}

Effects of IVC on genes involved in extracellular matrix synthesis and remodelling also appear in the transcriptome of blastocysts. This includes transcripts coding for matrix structural proteins (LUM, NDP, THBS1, CD9, JAM2, GJA1, COL3A1, LGALS3, $\angle G A L S 3 B P$ and $E D N 3$ ) and remodelling enzymes such as proteases SERPINE1, SERPINA5, PLAT and PRSS23 and hydroxylase PLOD2. Extracellular matrix components are crucial for proper intercellular communication and adhesion during embryo development (Aflalo et al. 2004). In particular, morula compaction and formation of the blastocoel are dependent on tight cellular junctions, allowing polarised trophoblast cells to generate a cavity by inward movement of water. Remodelling is essential for trophoblast invasion into the endometrium and formation of the placenta (Armant 2005). In the murine endometrium, expression of the small leucinerich proteoglycan called lumican (LUM, Supplementary Table 1) is regulated during decidualisation (San Martin et al. 2003), but the role of this molecule in embryo implantation remains unknown. Proteomic analysis of amniotic fluid has revealed that foetuses with Turner syndrome have a higher lumican content (Mavrou et al. 2008).

Impaired matrix remodelling capability in trophoblastic cells could interfere with the dynamics of endometrium invasion, with decisive consequences for embryo implantation (Dimitriadis et al. 2010). In the process of invasion by trophoblasts, the action of urokinase-type activator PLAU on plasminogen contributes to the activation of matrix metalloproteinase (Martinez-Hernandez et al. 2011). Expression of serine protease Prss23 has been detected in peri-implantation mouse embryos on day 7.5 but not in pre-implantation embryos on day 6.5 or earlier (Diao et al. 2013) and serine protease secretion is correlated positively with implantation potential (Brosens et al. 2014). Galectin 3 (LGASL3) promotes embryo implantation by regulating endometrial cell proliferation and adhesion through interaction with integrin $\beta 3$ (Yang et al. 2011), but oversecretion of Gal-3 is detrimental to trophoblast invasion. The receptivity of the human endometrium to blastocyst adhesion during the pre-implantation window depends in part on signal recognition via membrane domains rich in tetraspanin CD9, a receptor of pregnancy-specific glycoproteins (Wynne et al. 2006, Dominguez et al. 2010). Overexpression of CD9 in blastocysts could inhibit implantation by reducing embryo invasiveness (Liu et al. 2006).

\section{Embryo-maternal recognition}

Maternal-embryo recognition is based on the regulated expression of inflammatory signals by the embryo and the inhibition of the immune response of the endometrium. The transcriptome of IVC blastocysts appears to contain features of excessive inflammatory response that might explain the failure of the maternal-embryo recognition. Stressed embryos have shown repeatedly differential expression of genes involved in immune signalling (IFN-t, 
IL27RA, OAS1, PSMD1 and BOLA) and inflammation (TNFRSF1A, TNFAIP8L3). The cytokine IFN-t is well known in ungulate species to signal the presence of an embryo to the maternal immune system (Forde et al. 2015). However, it remains unclear how too much IFN-t would affect endometrial receptivity. Overproduction of inflammatory factors by the embryo might be perceived by the maternal immune system as a danger signal, and the endometrium might block trophoblast invasion to prevent wastage of resources on the development of an embryo of poor quality. Placenta-specific protein 8 (PLAC8) is involved in placental development and might have a role in blastocyst hatching (Rekik et al. 2011) and embryo-maternal recognition (Klein et al. 2006, Ghanem et al. 2011). Platelet-derived growth factor is expressed normally by the embryo and the endometrium (Jaber \& Kan 1998). PDGFc overexpression may interfere with implantation by inducing uterine fibrosis (Bonner 2004, Horne \& Critchley 2007), which might otherwise result from excessive inflammation due to embryonic distress signals.

\section{Mitochondrial signalling}

Much evidence suggests that mitochondria play a central role in proper embryo development and metabolic adaptation. The lactate production/oxygen consumption ratio (essentially the glycolysis/OXPHOS ratio), lipid utilisation rate and amino acid turnover are under mitochondrial control and have been found to be good predictors of embryo viability (Ballantyne 2008). Aneuploidy has been correlated with altered metabolic status (Picton et al. 2010) and slower development and decreased viability (Lee et al. 2015) in human pre-implantation embryos. Moreover, increased mitochondrial DNA in the trophectoderm is associated with aneuploidy in humans and is a predictor of the postimplantation potential of embryos (Fragouli et al. 2015). The replication of mitochondrial DNA is under dynamic regulation during pre-implantation development (Cagnone et al. 2016) and stress responses could trigger the release of this DNA into the culture medium (due to cell death or clearance of damaged mitochondria). Recent studies have shown that an increased copy number of the mtDNA genome in embryonic cells and in spent media is a sign of a metabolic response to developmental stress (Stigliani et al. 2013, 2014).

Chromosomal abnormalities such as aneuploidy occur because of improper separation of chromosomes during meiosis in gametes or mitosis in the early embryos. Some PGS studies have shown the impact of IVC on the increase in the number of aneuploid cells among mosaic embryos (Bergh et al. 2004, Elaimi et al. 2012), but the underlying mechanisms are not completely understood (Labrecque \& Sirard 2014, Taylor et al. 2014, Pfender et al. 2015). However, it appears likely that differential expression of genes controlling chromosomal segregation/ stability is involved (Treff et al. 2011, Vazquez-Diez et al. 2016). Moreover, communication between nuclear and mitochondrial DNA is crucial during meiosis, fertilisation and early pre-implantation development. Since the energetic metabolism is slowed-down until EGA, the early embryonic cleavages may not require important oxidative activity from the mitochondria. However, these early stages do require a synchronisation between the cytoplasmic accumulation of proteins, mRNA, mtDNA, etc. and the activation of the embryonic genome. In this context, intracellular bio-sensors such as the CHK2 kinase or the sirtuin deacetylases might intervene to communicate the state of cytoplasmic maturity to the nucleus, and regulate the proper segregation of chromosomes and the acquisition of developmental competence (Bolcun-Filas et al. 2014).

The response of embryos to IVC involves a variety of metabolic factors that act as signals (homeostatic sensors) of extracellular and intracellular conditions to which the cells adapt by modifying the developmental programme accordingly (Fig. 1). These sensors include notably the PI3K/AKT, mTORC and AMPK pathways, which are sensitive to the thermodynamic phosphate potential (Riley et al. 2005, Diaz-Ruiz et al. 2011, Guerke et al. 2016) and regulate energetic homeostasis (Li et al. 2013, Toyama et al. 2016). Other factors will also regulate mitochondrial metabolism, such as HIF1A in response to oxygen tension (Zhou et al. 2012), HNF4A in response to glucose concentration (Wang et al. 2000, Dankel et al. 2010), or PPARg and SREBP in response to lipid content. Others suggest that mitochondrial biogenesis is controlled in direct response to the energy demand via PGC1A or sirtuins and that these sensors should be targeted using suitable compounds to maintain mitochondrial homeostasis during IVC. For example, supplementing IVC medium with ADP and L-carnitine may be beneficial to OXPHOS, since they contribute to energy expenditure and lipid transport into the mitochondria. In addition, resveratrol (an activator of sirtuin deacetylases, which regulate proper mitochondrial function) could also enhance embryo quality through its action on mitochondrial maturation during oocyte growth and early embryonic development.

Changes in mitochondrial activity may also have an epigenetic impact on the developmental programming of energetic metabolism (metabolic memory) in the embryo. As biosensors of the surrounding milieu, mitochondria communicate with the nucleus to adjust cell metabolic homeostasis. In particular, mitochondrial production of acetyl-CoA and methyl groups, which are dependent on the availability of glucose, lipids (cholesterol) and amino acids (notably L-methionine, vitamin B12, folate and other substrates involved in one carbon metabolism), will regulate histone acetylation and the DNA methylation in the nucleus (Steegers-Theunissen et al. 2013, Xu \& Sinclair 2015). 


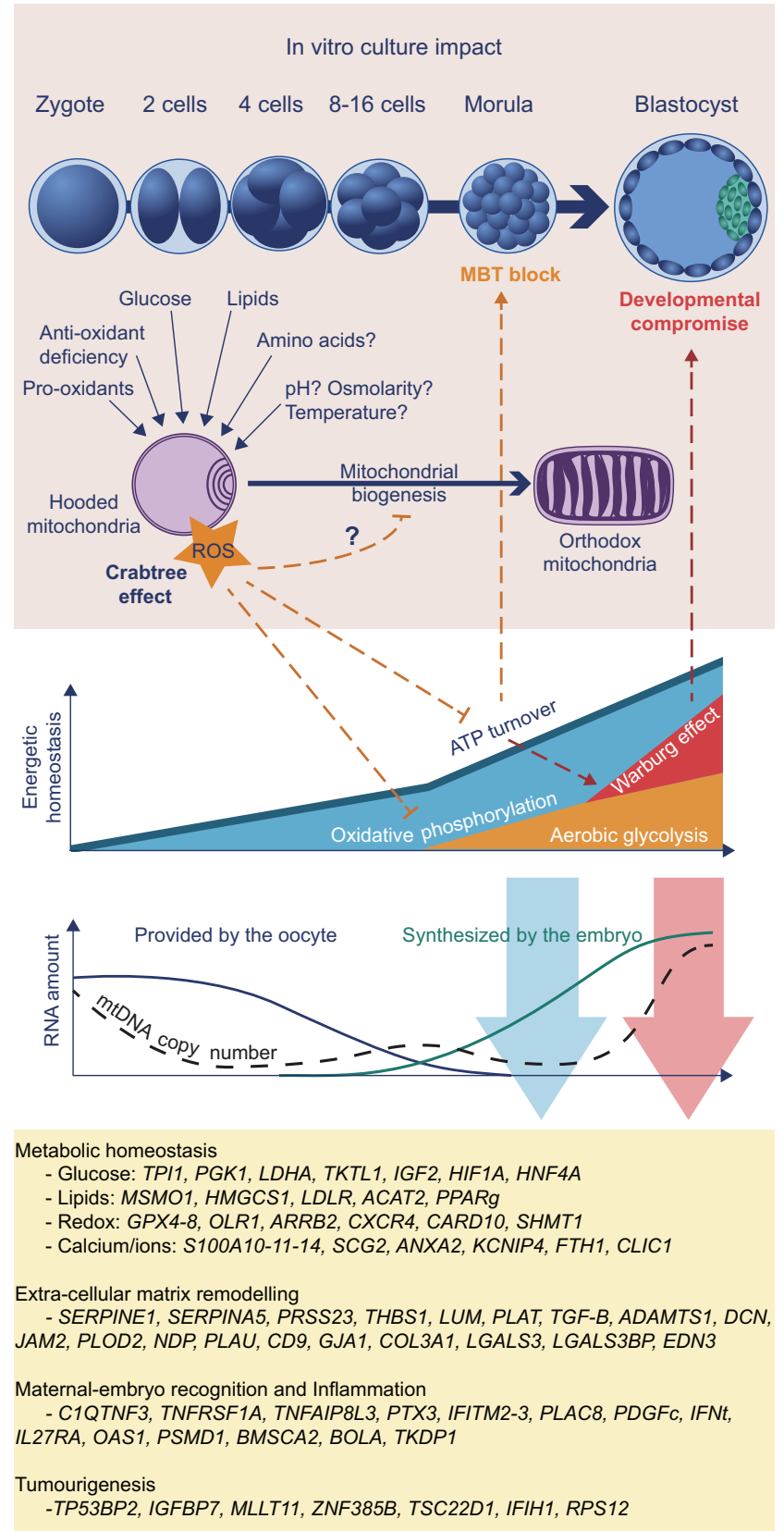

Figure 1 Proposed model for the IVC impact on the homeostasis of preimplantation development and the embryogenomic response associated with compromised embryonic quality. In this model, the IVC conditions impact the mitochondrial maturation in early developing embryos, leading to OXPHOS impairment and ATP deficiency after embryonic genome activation (8-16 cells stage in bovine embryos). In order to survive and overcome the morula-toblastocyst transition (MBT), embryos respond to IVC stress conditions by intensifying aerobic glycolysis (the Warburg effect), which creates a metabolic imbalance and ultimately compromises blastocyst quality. Such response induces a typical transcriptomic signature that should be considered when optimizing the IVC conditions to reduce mitochondrial stress in the embryos.

These so-called epigenetic marks regulate the expression of the genome to adjust the cellular homeostasis in response to the external energy supply
(Chason et al. 2011). Such regulation can be useful for short-term metabolic adaptation to overcome IVCrelated stress. However, early changes in epigenetic programming, specifically epigenomic upheaval during pre-implantation development, can have longterm consequences on health and disease (ChavattePalmer et al. 2016). IVC and serum in particular have been shown to affect the establishment of epigenetic marks notably in gene regions such as H19/IGF2 (Doherty et al. 2000, Khosla et al. 2001a), which are associated with developmental syndromes such as Beckwith-Wiedemann Syndrome or BWS (Lucifero et al. 2004, Fernandez-Gonzalez et al. 2007), thus providing compelling support for the hypothesis of the developmental origin of health and disease (Hart \& Norman 2013, Chavatte-Palmer et al. 2016).

\section{A unified mitochondrial hypothesis}

The various interpretations of the repeatedly observed responses of the transcriptome to stress associated with IVC converge on a unified hypothesis according to which the central cause of compromised development of embryos is disturbed mitochondrial homeostasis. Molecular genetic analysis has shown that mitochondria originated from bacterial endosymbiosis, which established effective intracellular communication between prokaryotic and proto-nuclear DNA genomes, leading ultimately to the development of the first eukaryotic cells (Wallace 2009). As energy control units, mitochondria play a fundamental role in cellular homeostasis and in functions such as cell division, pluripotency, differentiation and apoptosis. Their metabolic functions include production of reduced dinucleotides $\mathrm{NADH}$ and $\mathrm{FADH}_{2}$ via the tricarboxylic acid cycle and beta oxidation of fatty acids, oxidative phosphorylation of ADP to ATP (by the trans-membrane proton gradient generated by the electron transport chain), elimination of superoxide produced by the electron transport chain, production of ketone bodies such as hydroxybutyrate (as an alternative energy source), turnover of numerous amino acids via the TCA cycle, thiol metabolism, elimination of ammonia by the urea cycle, management of calcium pools, mitochondrial permeability transition, and the release of cytochrome $\mathrm{C}$ to induce apoptosis.

During oocyte maturation, mitochondria are in an immature state, containing few cristae and exhibiting a hooded shape (Scantland et al. 2014). This phenotype is maintained until embryonic compaction, when the demand for ATP increases. At this stage, mitochondria regain their regular shape, contain more cristae and produce most of the ATP made available to the cell by OXPHOS (Trimarchi et al. 2000). However, embryos produce ATP also by converting pyruvate into lactate, a process called aerobic glycolysis. Embryonic 
metabolism is thus similar to cancer cell metabolism, first described by Dr Otto Warburg, Kaiser-Wilhelm-Institut (now Max-Planck-Institut) für Biologie, Berlin-Dahlem, Germany in the early 1920s and then called the Warburg effect (Vander Heiden et al. 2009). Numerous genes involved in the Warburg effect are expressed normally during blastocyst development (Krisher \& Prather 2012, Redel et al. 2012), and this compensates for the limits on ATP synthesis via OXPHOS at low oxygen tension. Aerobic glycolysis also provides building blocks for anabolism in the developing embryos (e.g. production of nucleic acids from intermediates of the pentose phosphate pathway). In addition, the conversion of pyruvate to lactate limits the production of ROS that could otherwise arise from excessive OXPHOS activity.

Although post-EGA anaerobic glycolysis is normal and necessary (Krisher \& Prather 2012, Redel et al. 2012), overexpression of the Warburg-like signature might be an energetic compromise in response to stress during IVC. Such compromise could result from altered mitochondrial function, albeit the direct causal mechanism is still hypothetical. During the early cleavages of the zygote, mitochondria and intracellular metabolism in general are quiescent. Compared with in vivo, this metabolic quiescence is disturbed in vitro due to the presence of nutrients in excessive amounts and the accumulation of metabolic intermediates that overstimulate the mitochondria (a Crabtree-like effect) and alter the OXPHOS coupling efficiency. Moreover, mitochondria also sense changes in homeostatic parameters such as the redox potential or the amino acid concentration. External conditions could thus induce damaging stress and affect mitochondrial maturation during early cleavage, forcing embryos to cope with decreased production of ATP by OXPHOS at the morula-to-blastocyst transition and to adapt in order to overcome an energy deficit. Although this model needs further investigation, it proposes an explanation for the overexpression of the Warburg-like metabolism observed in IVC embryos (Fig. 1).

The Warburg-like signature includes biomarkers such as TPI1, a glycolic enzyme that is upregulated in cancer cells (Wang et al. 2013b, Poliakov et al. 2014). In addition, the extracellular matrix remodelling and inflammatory responses to IVC accompany transcriptomic changes are similar to those that accompany tumour progression and the micro-environmental modifications required for metastasis. Lumican, SERPINE1 and PLOD2 are involved in tumour invasion (Brezillon et al. 2013, Chen et al. 2015, Suh et al. 2015). Type I interferons have been shown to control the IFNR/STAT1-dependant expression of Warburg effect genes (Pitroda et al. 2009, Rautela et al. 2015) and to regulate tumour growth and chemoresistance (Sistigu et al. 2014, Rautela et al. 2015). Several other genes involved in tumorigenesis (MLLT11, ZNF385B, TSC22D1, IFIH1 and RPS12) are also overexpressed in IVC embryos, although their functions remain to be characterised. Moreover, alternative splicing of metabolic genes (which can be observed by RNA-seq or with the EmbryoGENE array) may control the Warburg-like effect in cancer cells (Redel et al. 2012, Yang \& Lu 2013, Yang et al. 2013) and should be investigated in IVC embryos.

The differential gene expression associated with the Warburg-like signature may represent either a transient status regulated by transcription factors or the induction of epigenetic changes, or both (Salilew-Wondim et al. 2015). Based on our microarray results, several DEGs appear to be controlled by epigenetic modifications or parental imprinting (the epigenetic extinction of maternal or paternal alleles). For example, differential DNA methylation regulates SERPINE1, which appears to support long-term memory of metabolic disorders (Lopez-Legarrea et al. 2013, Takizawa et al. 2013). A histone-modifying enzyme under TGFB1 stimulation targets the PLOD2 promoter (Gjaltema et al. 2015). Overexpression of IFN-t is associated with epigenetic reprogramming after somatic cell nuclear transfer in bovine elongated embryos (Rodriguez-Alvarez et al. 2010). In addition, IFN-t and IGF2 are regulated differently in slow-developing and fast-developing embryos (Gutierrez-Adan et al. 2004) and altered parental imprinting of IGF2 in embryonic stem cells is associated with aberrant development (Dean et al. 1998). It should interest researchers that loss of imprinting on IGF2, which increases IGF2 expression, is associated with mitochondrial OXPHOS deficiency, which causes cancer cells to shift toward glycolysis (Wallace \& Fan 2010). These results suggest strongly that overexpression of the Warburg effect in response to mitochondrial stress in culture can have profound effects on the metabolic memory of the embryo and thus will likely influence its long-term homeostasis.

\section{Conclusion}

The focus of this review is the identification of stress response genes that might provide valuable biomarkers of blastocyst quality. These markers draw attention to specific pathways that are subject to transcriptome plasticity during early embryonic development and which would therefore become targets for media optimisation. These stress-induced pathways expressed in cultured embryos suggest a unified hypothesis of metabolic compromise in response to mitochondrial insult and excessive upregulation of a Warburg-like effect (aerobic glycolysis). After EGA, the embryo normally turns to aerobic glycolysis to complement oxidative energy production at low oxygen tension, an adaptation that limits ROS production by OXPHOS and provides anabolic substrates required for cell proliferation. Mitochondria are immature and vulnerable during early cleavage, and their maturation under IVC conditions may be incomplete, leading 
to inadequate coupling efficiency during blastocyst development. In order to survive, embryos respond to IVC stress conditions by intensifying aerobic glycolysis (the Warburg effect), which creates a metabolic imbalance and ultimately reduces embryo quality. Moreover, the overexpression of a cancer-like developmental programme may compromise embryomaternal recognition, since the endometrium might block the invasion of metabolically uncontrolled cells. The early energetic adaptation to IVC might also induce epigenetic modifications that affect foetal growth and induce developmental syndromes after birth (De Rycke et al. 2002, Gosden et al. 2003, Denomme \& Mann 2012). In this equation, metabolic signalling is a critical factor for the establishment of a properly functioning embryonic epigenome. Culture media optimisation research therefore must take mitochondrial homeostasis into consideration in order to improve the quality of embryos and the health of offspring resulting from the use of assisted reproductive technologies.

\section{Supplementary data}

This is linked to the online version of the paper at http://dx.doi. org/10.1530/REP-16-0391.

\section{Declaration of interest}

The authors declare that there is no conflict of interest that could be perceived as prejudicing the impartiality of the research reported.

\section{Funding}

This research did not receive any specific grant from any funding agency in the public, commercial or not-for-profit sector.

\section{References}

Abe H, Yamashita S, Satoh T \& Hoshi H 2002 Accumulation of cytoplasmic lipid droplets in bovine embryos and cryotolerance of embryos developed in different culture systems using serum-free or serum-containing media. Molecular Reproduction and Development 61 57-66. (doi:10.1002/ mrd.1131)

Aflalo ED, Sod-Moriah UA, Potashnik G \& Har-Vardi I 2004 Differences in the implantation rates of rat embryos developed in vivo and in vitro: possible role for plasminogen activators. Fertility and Sterility $\mathbf{8 1}$ (Supplement 1) 780-785. (doi:10.1016/j.fertnstert.2003.10.014)

Agarwal A, Said TM, Bedaiwy MA, Banerjee J \& Alvarez JG 2006 Oxidative stress in an assisted reproductive techniques setting. Fertility and Sterility 86 503-512. (doi:10.1016/j.fertnstert.2006.02.088)

Arechiga CF, Ealy AD \& Hansen PJ 1995 Evidence that glutathione is involved in thermotolerance of preimplantation murine embryos. Biology of Reproduction 52 1296-1301. (doi:10.1095/biolreprod52.6.1296)

Armant DR 2005 Blastocysts don't go it alone. Extrinsic signals fine-tune the intrinsic developmental program of trophoblast cells. Developmental Biology 280 260-280. (doi:10.1016/j.ydbio.2005.02.009)

Balasubramanian S, Son WJ, Kumar BM, Ock SA, Yoo JG, Im GS, Choe SY \& Rho GJ 2007 Expression pattern of oxygen and stress-responsive gene transcripts at various developmental stages of in vitro and in vivo preimplantation bovine embryos. Theriogenology 68 265-275. (doi:10.1016/j.theriogenology.2007.05.044)

Ballantyne C 2008 Better tests boost IVF success. Nature Medicine 14 1169. (doi:10.1038/nm1108-1169a)

Baltz JM 2012 Media composition: salts and osmolality. Methods in Molecular Biology 912 61-80. (doi:10.1007/978-1-61779-971-6_5)

Bedaiwy MA, Falcone T, Mohamed MS, Aleem AA, Sharma RK, Worley SE, Thornton J \& Agarwal A 2004 Differential growth of human embryos in vitro: role of reactive oxygen species. Fertility and Sterility 82 593-600. (doi:10.1016/j.fertnstert.2004.02.121)

Bell CE, Lariviere NM, Watson PH \& Watson AJ 2009 Mitogen-activated protein kinase (MAPK) pathways mediate embryonic responses to culture medium osmolarity by regulating Aquaporin 3 and 9 expression and localization, as well as embryonic apoptosis. Human Reproduction 24 1373-1386. (doi:10.1093/humrep/dep010)

Bergh C, Loft A, Lundin K, Ziebe S, Nilsson L, Wikland M, Grondahl C \& Arce JC 2004 Chromosomal abnormality rate in human pre-embryos derived from in vitro fertilization cycles cultured in the presence of Follicular-Fluid Meiosis Activating Sterol (FF-MAS). Human Reproduction 19 2109-2117. (doi:10.1093/humrep/deh388)

Bermejo-Alvarez P, Rosenfeld CS \& Roberts RM 2012 Effect of maternal obesity on estrous cyclicity, embryo development and blastocyst gene expression in a mouse model. Human Reproduction 27 3513-3522. (doi:10.1093/humrep/des327)

Betts DH \& Madan P 2008 Permanent embryo arrest: molecular and cellular concepts. Molecular Human Reproduction 14 445-453. (doi:10.1093/molehr/gan035)

Bolcun-Filas E, Rinaldi VD, White ME \& Schimenti JC 2014 Reversal of female infertility by Chk2 ablation reveals the oocyte DNA damage checkpoint pathway. Science 343 533-536. (doi:10.1126/ science.1247671)

Bonilla AQ, Oliveira LJ, Ozawa M, Newsom EM, Lucy MC \& Hansen PJ 2011 Developmental changes in thermoprotective actions of insulin-like growth factor-1 on the preimplantation bovine embryo. Molecular and Cellular Endocrinology 332 170-179. (doi:10.1016/j.mce.2010.10.009)

Bonner JC 2004 Regulation of PDGF and its receptors in fibrotic diseases. Cytokine and Growth Factor Reviews 15 255-273. (doi:10.1016/j. cytogfr.2004.03.006)

Brezillon S, Pietraszek K, Maquart FX \& Wegrowski Y 2013 Lumican effects in the control of tumour progression and their links with metalloproteinases and integrins. FEBS Journal 280 2369-2381. (doi:10.1111/febs.12210)

Brinster RL 1963 A method for in vitro cultivation of mouse ova from two-cell to blastocyst. Experimental Cell Research 32 205-208. (doi:10.1016/0014-4827(63)90093-4)

Brinster RL \& Troike DE 1979 Requirements for blastocyst development in vitro. Journal of Animal Science 49 (Supplement 2) 26-34. (doi:10.2527/ jas1979.49126x)

Brison DR, Sturmey RG \& Leese HJ 2014 Metabolic heterogeneity during preimplantation development: the missing link? Human Reproduction Update 20 632-640. (doi:10.1093/humupd/dmu018)

Brosens JJ, Salker MS, Teklenburg G, Nautiyal J, Salter S, Lucas ES, Steel JH, Christian M, Chan YW, Boomsma CM et al. 2014 Uterine selection of human embryos at implantation. Scientific Reports 43894. (doi:10.1038/srep03894)

Cagnone GL \& Sirard MA 2013 Transcriptomic signature to oxidative stress exposure at the time of embryonic genome activation in bovine blastocysts. Molecular Reproduction and Development 80 297-314. (doi:10.1002/mrd.22162)

Cagnone G \& Sirard MA 2014 The impact of exposure to serum lipids during in vitro culture on the transcriptome of bovine blastocysts. Theriogenology 81 712-722, e711-e713. (doi:10.1016/j. theriogenology.2013.12.005)

Cagnone GL, Dufort I, Vigneault C \& Sirard MA 2012 Differential gene expression profile in bovine blastocysts resulting from hyperglycemia exposure during early cleavage stages. Biology of Reproduction 8650. (doi:10.1095/biolreprod.111.094391)

Cagnone GL, Tsai TS, Makanji Y, Matthews P, Gould J, Bonkowski MS, Elgass KD, Wong AS, Wu LE, McKenzie M et al. 2016 Restoration of normal embryogenesis by mitochondrial supplementation in pig oocytes exhibiting mitochondrial DNA deficiency. Scientific Reports 623229. (doi:10.1038/srep23229) 
Chason RJ, Csokmay J, Segars JH, DeCherney AH \& Armant DR 2011 Environmental and epigenetic effects upon preimplantation embryo metabolism and development. Trends in Endocrinology and Metabolism 22 412-420. (doi:10.1016/j.tem.2011.05.005)

Chavatte-Palmer P, Tarrade A, Kiefer H, Duranthon V \& Jammes H 2016 Breeding animals for quality products: not only genetics. Reproduction Fertility and Development 28 94-111. (doi:10.1071/ RD15353)

Chen Y, Terajima M, Yang Y, Sun L, Ahn YH, Pankova D, Puperi DS, Watanabe T, Kim MP, Blackmon SH et al. 2015 Lysyl hydroxylase 2 induces a collagen cross-link switch in tumor stroma. Journal of Clinical Investigation 125 1147-1162. (doi:10.1172/JCI74725)

Chi MM, Hoehn A \& Moley KH 2002 Metabolic changes in the glucoseinduced apoptotic blastocyst suggest alterations in mitochondrial physiology. American Journal of Physiology: Endocrinology and Metabolism 283 E226-E232. (doi:10.1152/ajpendo.00046.2002)

Dagilgan S, Dundar-Yenilmez E, Tuli A, Urunsak IF \& Erdogan S 2014 Evaluation of intracellular $\mathrm{pH}$ regulation and alkalosis defense mechanisms in preimplantation embryos. Theriogenology $\mathbf{8 3}$ 1075-1084. (doi:10.1016/j.theriogenology.2014.12.011)

Dankel SN, Hoang T, Flageng MH, Sagen JV \& Mellgren G 2010 cAMP-mediated regulation of HNF-4alpha depends on the level of coactivator PGC-1alpha. Biochimica et Biophysica Acta 1803 1013-1019. (doi:10.1016/j.bbamcr.2010.05.008)

De Rycke M, Liebaers I \& Van Steirteghem A 2002 Epigenetic risks related to assisted reproductive technologies: risk analysis and epigenetic inheritance. Human Reproduction 17 2487-2494. (doi:10.1093/ humrep/17.10.2487)

Dean W, Bowden L, Aitchison A, Klose J, Moore T, Meneses JJ, Reik W \& Feil R 1998 Altered imprinted gene methylation and expression in completely ES cell-derived mouse fetuses: association with aberrant phenotypes. Development 125 2273-2282.

Denomme MM \& Mann MR 2012 Genomic imprints as a model for the analysis of epigenetic stability during assisted reproductive technologies. Reproduction 144 393-409. (doi:10.1530/REP-12-0237)

Diao H, Xiao S, Li R, Zhao F \& Ye X 2013 Distinct spatiotemporal expression of serine proteases Prss23 and Prss35 in periimplantation mouse uterus and dispensable function of Prss35 in fertility. PLOS ONE 8 e56757. (doi:10.1371/journal.pone.0056757)

Diaz-Ruiz R, Averet N, Araiza D, Pinson B, Uribe-Carvajal S, Devin A \& Rigoulet M 2008 Mitochondrial oxidative phosphorylation is regulated by fructose 1,6-bisphosphate. A possible role in Crabtree effect induction?. Journal of Biological Chemistry 283 26948-26955. (doi:10.1074/jbc.m800408200)

Diaz-Ruiz R, Rigoulet M \& Devin A 2011 The Warburg and Crabtree effects: on the origin of cancer cell energy metabolism and of yeast glucose repression. Biochimica et Biophysica Acta 1807 568-576. (doi:10.1016/j.bbabio.2010.08.010)

Dimitriadis E, Nie G, Hannan NJ, Paiva P \& Salamonsen LA 2010 Local regulation of implantation at the human fetal-maternal interface. International Journal of Developmental Biology $\mathbf{5 4}$ 313-322. (doi:10.1387/ijdb.082772ed)

Doherty AS, Mann MR, Tremblay KD, Bartolomei MS \& Schultz RM 2000 Differential effects of culture on imprinted H19 expression in the preimplantation mouse embryo. Biology of Reproduction 62 1526-1535. (doi:10.1095/biolreprod62.6.1526)

Dominguez F, Simon C, Quinonero A, Ramirez MA, Gonzalez-Munoz E, Burghardt H, Cervero A, Martinez S, Pellicer A, Palacin M et al. 2010 Human endometrial CD98 is essential for blastocyst adhesion. PLoS ONE 5 e13380. (doi:10.1371/journal.pone.0013380)

Downs SM \& Dow MP 1991 Hypoxanthine-maintained two-cell block in mouse embryos: dependence on glucose and effect of hypoxanthine phosphoribosyltransferase inhibitors. Biology of Reproduction $\mathbf{4 4}$ 1025-1039. (doi:10.1095/biolreprod44.6.1025)

Edwards JL \& Hansen PJ 1996 Elevated temperature increases heat shock protein 70 synthesis in bovine two-cell embryos and compromises function of maturing oocytes. Biology of Reproduction 55 341-346. (doi:10.1095/biolreprod55.2.341)

El-Sayed A, Hoelker M, Rings F, Salilew D, Jennen D, Tholen E, Sirard MA, Schellander K \& Tesfaye D 2006 Large-scale transcriptional analysis of bovine embryo biopsies in relation to pregnancy success after transfer to recipients. Physiological Genomics 28 84-96. (doi:10.1152/ physiolgenomics.00111.2006)
Elaimi A, Gardner K, Kistnareddy K \& Harper J 2012 The effect of GMCSF on development and aneuploidy in murine blastocysts. Human Reproduction 27 1590-1595. (doi:10.1093/humrep/des108)

Fernandez-Gonzalez R, Ramirez MA, Bilbao A, De Fonseca FR \& Gutierrez-Adan A 2007 Suboptimal in vitro culture conditions: an epigenetic origin of long-term health effects. Molecular Reproduction and Development 74 1149-1156. (doi:10.1002/mrd.20746)

Feugang JM, Van Langendonckt A, Sayoud H, Rees JF, Pampfer S, Moens A, Dessy F \& Donnay I 2003 Effect of prooxidant agents added at the morula/blastocyst stage on bovine embryo development, cell death and glutathione content. Zygote 11 107-118. (doi:10.1017/ S0967199403002144)

Feugang JM, Donnay I, Mermillod P, Marchandise J \& Lequarre AS 2005 Impact of pro-oxidant agents on the morula-blastocyst transition in bovine embryos. Molecular Reproduction and Development 71 339-346. (doi:10.1002/mrd.20262)

Finger BJ, Harvey AJ, Green MP \& Gardner DK 2015 Combined parental obesity negatively impacts preimplantation mouse embryo development, kinetics, morphology and metabolism. Human Reproduction $\mathbf{3 0}$ 2084-2096. (doi:10.1093/humrep/dev142)

Fissore R, O'Keefe S \& Kiessling AA 1992 Purine-induced block to mouse embryo cleavage is reversed by compounds that elevate cyclic adenosine monophosphate. Biology of Reproduction 47 1105-1112. (doi:10.1095/ biolreprod47.6.1105)

Fong B, Watson PH \& Watson AJ 2007 Mouse preimplantation embryo responses to culture medium osmolarity include increased expression of CCM2 and p38 MAPK activation. BMC Developmental Biology 72. (doi:10.1186/1471-213X-7-2)

Forde N, Bazer FW, Spencer TE \& Lonergan P 2015 'Conceptualizing' the endometrium: identification of conceptus-derived proteins during early pregnancy in cattle. Biology of Reproduction 92 156. (doi:10.1095/ biolreprod.115.129296)

Fragouli E, Spath K, Alfarawati S, Kaper F, Craig A, Michel CE, Kokocinski F, Cohen J, Munne S \& Wells D 2015 Altered levels of mitochondrial DNA are associated with female age, aneuploidy, and provide an independent measure of embryonic implantation potential. PLoS Genetics 11 e1005241. (doi:10.1371/journal.pgen.1005241)

Fujitani Y, Kasai K, Ohtani S, Nishimura K, Yamada M \& Utsumi K 1997 Effect of oxygen concentration and free radicals on in vitro development of in vitro-produced bovine embryos. Journal of Animal Science $\mathbf{7 5}$ 483-489. (doi:10.2527/1997.752483x)

Gad A, Hoelker M, Besenfelder U, Havlicek V, Cinar U, Rings F, Held E, Dufort I, Sirard MA, Schellander K et al. 2012 Molecular mechanisms and pathways involved in bovine embryonic genome activation and their regulation by alternative in vivo and in vitro culture conditions. Biology of Reproduction 87 100. (doi:10.1095/biolreprod.112.099697)

Gardiner CS \& Reed DJ 1994 Status of glutathione during oxidant-induced oxidative stress in the preimplantation mouse embryo. Biology of Reproduction 51 1307-1314. (doi:10.1095/biolreprod51.6.1307)

Gardner DK 2016 The impact of physiological oxygen during culture, and vitrification for cryopreservation, on the outcome of extended culture in human IVF. Reproductive Biomedicine Online 32 137-141. (doi:10.1016/j.rbmo.2015.11.008)

Ghanem N, Salilew-Wondim D, Gad A, Tesfaye D, Phatsara C, Tholen E, Looft C, Schellander K \& Hoelker M 2011 Bovine blastocysts with developmental competence to term share similar expression of developmentally important genes although derived from different culture environments. Reproduction 142 551-564. (doi:10.1530/REP-10-0476)

Gjaltema RA, de Rond S, Rots MG \& Bank RA 2015 Procollagen lysyl hydroxylase 2 expression is regulated by an alternative downstream transforming growth factor beta-1 activation mechanism. Journal of Biological Chemistry $290 \quad$ 28465-28476. (doi:10.1074/jbc. M114.634311)

Gosden R, Trasler J, Lucifero D \& Faddy M 2003 Rare congenital disorders, imprinted genes, and assisted reproductive technology. Lancet $\mathbf{3 6 1}$ 1975-1977. (doi:10.1016/S0140-6736(03)13592-1)

Guerin P, El Mouatassim S \& Menezo Y 2001 Oxidative stress and protection against reactive oxygen species in the pre-implantation embryo and its surroundings. Human Reproduction Update 7 175-189. (doi:10.1093/humupd/7.2.175)

Guerke J, Schindler M, Pendzialek M, Thieme R, Grybel KJ, Heller R, Spengler K, Fleming T, Fischer B \& Navarrete Santos A 2016 Maternal diabetes promotes mTORC1 downstream signalling in rabbit 
preimplantation embryos. Reproduction 151 465-476. (doi:10.1530/ REP-15-0523)

Gutierrez-Adan A, Rizos D, Fair T, Moreira PN, Pintado B, de la Fuente J, Boland MP \& Lonergan P 2004 Effect of speed of development on mRNA expression pattern in early bovine embryos cultured in vivo or in vitro. Molecular Reproduction and Development 68 441-448. (doi:10.1002/ mrd.20113)

Hart R \& Norman RJ 2013 The longer-term health outcomes for children born as a result of IVF treatment: part I - general health outcomes. Human Reproduction Update 19 232-243. (doi:10.1093/humupd/ dms062)

Harvey AJ, Kind KL, Pantaleon M, Armstrong DT \& Thompson JG 2004a Oxygen-regulated gene expression in bovine blastocysts. Biology of Reproduction 71 1108-1119. (doi:10.1095/biolreprod. 104.028639)

Harvey AJ, Kind KL \& Thompson JG 2004b Effect of the oxidative phosphorylation uncoupler 2,4-dinitrophenol on hypoxia-inducible factor-regulated gene expression in bovine blastocysts. Reproduction Fertility and Development 16 665-673. (doi:10.1071/RD04027)

Haucke E, Navarrete Santos A, Simm A, Henning C, Glomb MA, Gurke J, Schindler M \& Fischer B 2014 Accumulation of advanced glycation end products in the rabbit blastocyst under maternal diabetes. Reproduction 148 169-178. (doi:10.1530/REP-14-0149)

Heras S, De Coninck DI, Van Poucke M, Goossens K, Bogado Pascottini O, Van Nieuwerburgh F, Deforce D, De Sutter P, Leroy JL, Gutierrez-Adan A et al. 2016 Suboptimal culture conditions induce more deviations in gene expression in male than female bovine blastocysts. BMC Genomics 17 72. (doi:10.1186/s12864-016-2393-z)

Highet AR, Khoda SM, Buckberry S, Leemaqz S, Bianco-Miotto T, Harrington E, Ricciardelli C \& Roberts CT 2015 Hypoxia induced HIF-1/ HIF-2 activity alters trophoblast transcriptional regulation and promotes invasion. European Journal of Cell Biology 94 589-602. (doi:10.1016/j. ejcb.2015.10.004)

Horne AW \& Critchley HO 2007 The effect of uterine fibroids on embryo implantation. Seminars in Reproductive Medicine 25 483-489. (doi:10.1055/s-2007-991046)

Huang W, Yandell BS \& Khatib H 2010 Transcriptomic profiling of bovine IVF embryos revealed candidate genes and pathways involved in early embryonic development. BMC Genomics 11 23. (doi:10.1186/14712164-11-23)

Im GS, Samuel M, Lai L, Hao Y \& Prather RS 2007 Development and calcium level changes in pre-implantation porcine nuclear transfer embryos activated with 6-DMAP after fusion. Molecular Reproduction and Development 74 1158-1164. (doi:10.1002/mrd.20492)

Jaber L \& Kan FW 1998 Non-identical distribution pattern of epidermal growth factor and platelet-derived growth factor in the mouse uterus during the oestrous cycle and early pregnancy. Histochemical Journal 30 711-722. (doi:10.1023/A:1003441904274)

Jones GM, Cram DS, Song B, Kokkali G, Pantos K \& Trounson AD 2008 Novel strategy with potential to identify developmentally competent IVF blastocysts. Human Reproduction 23 1748-1759.

Jousan FD \& Hansen PJ 2007 Insulin-like growth factor-I promotes resistance of bovine preimplantation embryos to heat shock through actions independent of its anti-apoptotic actions requiring $\mathrm{PI} 3 \mathrm{~K}$ signaling. Molecular Reproduction and Development 74 189-196. (doi:10.1002/ mrd.20527)

Karja NW, Kikuchi K, Fahrudin M, Ozawa M, Somfai T, Ohnuma K, Noguchi J, Kaneko H \& Nagai T 2006 Development to the blastocyst stage, the oxidative state, and the quality of early developmental stage of porcine embryos cultured in alteration of glucose concentrations in vitro under different oxygen tensions. Reproductive Biology and Endocrinology 4 54. (doi:10.1186/1477-7827-4-54)

Khosla S, Dean W, Brown D, Reik W \& Feil R 2001a Culture of preimplantation mouse embryos affects fetal development and the expression of imprinted genes. Biology of Reproduction 64 918-926. (doi:10.1095/biolreprod64.3.918)

Khosla S, Dean W, Reik W \& Feil R 2001b Culture of preimplantation embryos and its long-term effects on gene expression and phenotype. Human Reproduction Update 7 419-427. (doi:10.1093/ humupd/7.4.419)

Khurana NK \& Niemann H 2000 Energy metabolism in preimplantation bovine embryos derived in vitro or in vivo. Biology of Reproduction 62 847-856. (doi:10.1095/biolreprod62.4.847)
Kim JY, Song EH, Lee HJ, Oh YK, Choi KH, Yu DY, Park SI, Seong JK \& Kim WH 2010 HBx-induced hepatic steatosis and apoptosis are regulated by TNFR1 - and NF-kappaB-dependent pathways. Journal of Molecular Biology 397 917-931. (doi:10.1016/j.jmb.2010.02.016)

Kitagawa Y, Suzuki K, Yoneda A \& Watanabe T 2004 Effects of oxygen concentration and antioxidants on the in vitro developmental ability, production of reactive oxygen species (ROS), and DNA fragmentation in porcine embryos. Theriogenology 62 1186-1197. (doi:10.1016/j. theriogenology.2004.01.011)

Kleijkers SH, Eijssen LM, Coonen E, Derhaag JG, Mantikou E, Jonker MJ, Mastenbroek S, Repping S, Evers JL, Dumoulin JC et al. 2015 Differences in gene expression profiles between human preimplantation embryos cultured in two different IVF culture media. Human Reproduction 30 2303-2311. (doi:10.1093/humrep/dev179)

Klein C, Bauersachs S, Ulbrich SE, Einspanier R, Meyer HH, Schmidt SE, Reichenbach HD, Vermehren M, Sinowatz F, Blum H et al. 2006 Monozygotic twin model reveals novel embryo-induced transcriptome changes of bovine endometrium in the preattachment period. Biology of Reproduction 74 253-264. (doi:10.1095/biolreprod.105.046748)

Kopp A, Bala M, Buechler C, Falk W, Gross P, Neumeier M, Scholmerich J \& Schaffler A 2010 C1q/TNF-related protein-3 represents a novel and endogenous lipopolysaccharide antagonist of the adipose tissue. Endocrinology 151 5267-5278. (doi:10.1210/en.2010-0571)

Krisher RL \& Prather RS 2012 A role for the Warburg effect in preimplantation embryo development: metabolic modification to support rapid cell proliferation. Molecular Reproduction and Development 79 311-320. (doi:10.1002/mrd.22037)

Krisher RL \& Wheeler MB 2010 Towards the use of microfluidics for individual embryo culture. Reproduction Fertility and Development 22 32-39. (doi:10.1071/RD09219)

Labrecque R \& Sirard MA 2014 The study of mammalian oocyte competence by transcriptome analysis: progress and challenges. Molecular Human Reproduction 20 103-116. (doi:10.1093/molehr/gat082)

Lazzari G, Wrenzycki C, Herrmann D, Duchi R, Kruip T, Niemann H \& Galli C 2002 Cellular and molecular deviations in bovine in vitro-produced embryos are related to the large offspring syndrome. Biology of Reproduction 67 767-775.

Lee KF, Chow JF, Xu JS, Chan ST, Ip SM \& Yeung WS 2001 A comparative study of gene expression in murine embryos developed in vivo, cultured in vitro, and cocultured with human oviductal cells using messenger ribonucleic acid differential display. Biology of Reproduction 64 910-917. (doi:10.1095/biolreprod64.3.910)

Lee YS, Thouas GA \& Gardner DK 2015 Developmental kinetics of cleavage stage mouse embryos are related to their subsequent carbohydrate and amino acid utilization at the blastocyst stage. Human Reproduction 30 543-552. (doi:10.1093/humrep/deu334)

Leese HJ, Donnay I \& Thompson JG 1998 Human assisted conception: a cautionary tale. Lessons from domestic animals. Human Reproduction 13 (Supplement 4) 184-202. (doi:10.1093/humrep/13.suppl_4.184)

Leroy JL, Van Hoeck V, Clemente M, Rizos D, Gutierrez-Adan A, Van Soom A, Uytterhoeven M \& Bols PE 2010 The effect of nutritionally induced hyperlipidaemia on in vitro bovine embryo quality. Human Reproduction 25 768-778. (doi:10.1093/humrep/dep420)

Leunda-Casi A, Genicot G, Donnay I, Pampfer S \& De Hertogh R 2002 Increased cell death in mouse blastocysts exposed to high d-glucose in vitro: implications of an oxidative stress and alterations in glucose metabolism. Diabetologia 45 571-579. (doi:10.1007/s00125-0010752-y)

Li C, Li Y, He L, Agarwal AR, Zeng N, Cadenas E \& Stiles BL 2013 PI3K/ AKT signaling regulates bioenergetics in immortalized hepatocytes. Free Radical Biology and Medicine 60 29-40. (doi:10.1016/j. freeradbiomed.2013.01.013)

Liu WM, Cao YJ, Yang YJ, Li J, Hu Z \& Duan EK 2006 Tetraspanin CD9 regulates invasion during mouse embryo implantation. Journal of Molecular Endocrinology 36 121-130. (doi:10.1677/jme.1.01910)

Lopez-Legarrea P, Mansego ML, Zulet MA \& Martinez JA 2013 SERPINE1, $\mathrm{PAI}-1$ protein coding gene, methylation levels and epigenetic relationships with adiposity changes in obese subjects with metabolic syndrome features under dietary restriction. Journal of Clinical Biochemistry and Nutrition 53 139-144. (doi:10.3164/jcbn.13-54)

Lucifero D, Chaillet JR \& Trasler JM 2004 Potential significance of genomic imprinting defects for reproduction and assisted reproductive technology. Human Reproduction Update $103-18$. (doi:10.1093/humupd/dmh002) 
Machaty Z, Thompson JG, Abeydeera LR, Day BN \& Prather RS 2001 Inhibitors of mitochondrial ATP production at the time of compaction improve development of in vitro produced porcine embryos. Molecular Reproduction and Development $\mathbf{5 8}$ 39-44. (doi:10.1002/10982795(200101)58:1 \&lt;39::AID-MRD6\&gt;3.0.CO;2-B)

Mantikou E, Jonker MJ, Wong KM, van Montfoort AP, de Jong M, Breit TM, Repping S \& Mastenbroek S 2016 Factors affecting the gene expression of in vitro cultured human preimplantation embryos. Human Reproduction 31 298-311. (doi:10.1093/humrep/dev306)

Market Velker BA, Denomme MM \& Mann MR 2012 Loss of genomic imprinting in mouse embryos with fast rates of preimplantation development in culture. Biology of Reproduction 86 143, 141-116. (doi:10.1095/biolreprod.112.098871)

Martinez-Hernandez MG, Baiza-Gutman LA, Castillo-Trapala A \& Armant DR 2011 Regulation of proteinases during mouse periimplantation development: urokinase-type plasminogen activator expression and cross talk with matrix metalloproteinase 9. Reproduction 141 227-239. (doi:10.1530/REP-10-0334)

Matsukawa T, Ikeda S, Imai H \& Yamada M 2002 Alleviation of the two-cell block of ICR mouse embryos by polyaminocarboxylate metal chelators. Reproduction 124 65-71. (doi:10.1530/rep.0.1240065)

Mavrou A, Anagnostopoulos AK, Kolialexi A, Vougas K, Papantoniou N, Antsaklis A, Fountoulakis M \& Tsangaris GT 2008 Proteomic analysis of amniotic fluid in pregnancies with Turner syndrome fetuses. Journal of Proteome Research 7 1862-1866. (doi:10.1021/pr700588u)

McKiernan SH \& Bavister BD 1994 Timing of development is a critical parameter for predicting successful embryogenesis. Human Reproduction 9 2123-2129.

McPherson NO, Bakos HW, Owens JA, Setchell BP \& Lane M 2013 Improving metabolic health in obese male mice via diet and exercise restores embryo development and fetal growth. PLOS ONE 8 e71459. (doi:10.1371/journal.pone.0071459)

Minge CE, Bennett BD, Norman RJ \& Robker RL 2008 Peroxisome proliferator-activated receptor-gamma agonist rosiglitazone reverses the adverse effects of diet-induced obesity on oocyte quality. Endocrinology 149 2646-2656. (doi:10.1210/en.2007-1570)

Mitchell M, Cashman KS, Gardner DK, Thompson JG \& Lane M 2009 Disruption of mitochondrial malate-aspartate shuttle activity in mouse blastocysts impairs viability and fetal growth. Biology of Reproduction 80 295-301. (doi:10.1095/biolreprod.108.069864)

Moley KH, Chi MM, Manchester JK, McDougal DB \& Lowry OH 1996 Alterations of intraembryonic metabolites in preimplantation mouse embryos exposed to elevated concentrations of glucose: a metabolic explanation for the developmental retardation seen in preimplantation embryos from diabetic animals. Biology of Reproduction 54 1209-1216. (doi:10.1095/biolreprod54.6.1209)

Moley KH, Chi MM, Knudson CM, Korsmeyer SJ \& Mueckler MM 1998 Hyperglycemia induces apoptosis in pre-implantation embryos through cell death effector pathways. Nature Medicine 4 1421-1424. (doi:10.1038/4013)

Morrison J, Knoll K, Hessner MJ \& Liang M 2004 Effect of high glucose on gene expression in mesangial cells: upregulation of the thiol pathway is an adaptational response. Physiological Genomics 17 271-282. (doi:10.1152/physiolgenomics.00031.2004)

Nair P 2008 As IVF becomes more common, some concerns remain. Nature Medicine 14 1171. (doi:10.1038/nm1108-1171)

Nasr-Esfahani MM \& Johnson MH 1991 The origin of reactive oxygen species in mouse embryos cultured in vitro. Development 113 551-560.

Nasr-Esfahani MH \& Johnson MH 1992 Quantitative analysis of cellular glutathione in early preimplantation mouse embryos developing in vivo and in vitro. Human Reproduction 7 1281-1290.

Nasr-Esfahani MH, Aitken JR \& Johnson MH 1990 Hydrogen peroxide levels in mouse oocytes and early cleavage stage embryos developed in vitro or in vivo. Development 109 501-507.

Nelissen EC, Van Montfoort AP, Coonen E, Derhaag JG, Geraedts JP, Smits LJ, Land JA, Evers JL \& Dumoulin JC 2012 Further evidence that culture media affect perinatal outcome: findings after transfer of fresh and cryopreserved embryos. Human Reproduction 27 1966-1976. (doi:10.1093/humrep/des145)

Niemann H \& Wrenzycki C 2000 Alterations of expression of developmentally important genes in preimplantation bovine embryos by in vitro culture conditions: implications for subsequent development. Theriogenology 53 21-34.
Nishikawa T, Edelstein D, Du XL, Yamagishi S, Matsumura T, Kaneda Y, Yorek MA, Beebe D, Oates PJ, Hammes HP et al. 2000 Normalizing mitochondrial superoxide production blocks three pathways of hyperglycaemic damage. Nature 404 787-790. (doi:10.1038/35008121)

Orsi NM \& Leese HJ 2001 Protection against reactive oxygen species during mouse preimplantation embryo development: role of EDTA, oxygen tension, catalase, superoxide dismutase and pyruvate. Molecular Reproduction and Development 59 44-53. (doi:10.1002/mrd.1006)

Pampfer S, Vanderheyden I, McCracken JE, Vesela J \& De Hertogh R 1997 Increased cell death in rat blastocysts exposed to maternal diabetes in utero and to high glucose or tumor necrosis factor-alpha in vitro. Development 124 4827-4836.

Pantaleon M 2015 The role of hexosamine biosynthesis and signaling in early development. Advances in Experimental Medicine and Biology $\mathbf{8 4 3}$ 53-76. (doi:10.1007/978-1-4939-2480-6_3)

Pantaleon M, Tan HY, Kafer GR \& Kaye PL 2010 Toxic effects of hyperglycemia are mediated by the hexosamine signaling pathway and o-linked glycosylation in early mouse embryos. Biology of Reproduction 82 751-758. (doi:10.1095/biolreprod.109.076661)

Pavlinkova G, Salbaum JM \& Kappen C 2009 Maternal diabetes alters transcriptional programs in the developing embryo. BMC Genomics $\mathbf{1 0}$ 274. (doi:10.1186/1471-2164-10-274)

Perez-Crespo M, Ramirez MA, Fernandez-Gonzalez R, Rizos D, Lonergan P, Pintado B \& Gutierrez-Adan A 2005 Differential sensitivity of male and female mouse embryos to oxidative induced heat-stress is mediated by glucose-6-phosphate dehydrogenase gene expression. Molecular Reproduction and Development 72 502-510. (doi:10.1002/ mrd.20366)

Pfender S, Kuznetsov V, Pasternak M, Tischer T, Santhanam B \& Schuh M 2015 Live imaging RNAi screen reveals genes essential for meiosis in mammalian oocytes. Nature 524 239-242. (doi:10.1038/nature14568)

Picton HM, Elder K, Houghton FD, Hawkhead JA, Rutherford AJ, Hogg JE, Leese HJ \& Harris SE 2010 Association between amino acid turnover and chromosome aneuploidy during human preimplantation embryo development in vitro. Molecular Human Reproduction 16 557-569. (doi:10.1093/molehr/gaq040)

Pitroda SP, Wakim BT, Sood RF, Beveridge MG, Beckett MA, MacDermed DM, Weichselbaum RR \& Khodarev NN 2009 STAT1dependent expression of energy metabolic pathways links tumour growth and radioresistance to the Warburg effect. BMC Medicine 768. (doi:10.1186/1741-7015-7-68)

Plourde D, Vigneault C, Lemay A, Breton L, Gagne D, Laflamme I, Blondin P \& Robert C 2012 Contribution of oocyte source and culture conditions to phenotypic and transcriptomic variation in commercially produced bovine blastocysts. Theriogenology 78 116-131, e111-113. (doi:10.1016/j.theriogenology.2012.01.027)

Poliakov E, Managadze D \& Rogozin IB 2014 Generalized portrait of cancer metabolic pathways inferred from a list of genes overexpressed in cancer. Genetics Research International 2014646193. (doi:10.1155/2014/646193)

Rautela J, Baschuk N, Slaney CY, Jayatilleke KM, Xiao K, Bidwell BN, Lucas EC, Hawkins ED, Lock P, Wong CS et al. 2015 Loss of host type-I IFN signaling accelerates metastasis and impairs NK-cell antitumor function in multiple models of breast cancer. Cancer Immunology Research 3 1207-1217. (doi:10.1158/2326-6066.CIR-15-0065)

Redel BK, Brown AN, Spate LD, Whitworth KM, Green JA \& Prather RS 2012 Glycolysis in preimplantation development is partially controlled by the Warburg Effect. Molecular Reproduction and Development $\mathbf{7 9}$ 262-271. (doi:10.1002/mrd.22017)

Rekik W, Dufort I \& Sirard MA 2011 Analysis of the gene expression pattern of bovine blastocysts at three stages of development. Molecular Reproduction and Development 78 226-240. (doi:10.1002/ mrd.21286)

Richards T, Wang F, Liu L \& Baltz JM 2010 Rescue of postcompactionstage mouse embryo development from hypertonicity by amino acid transporter substrates that may function as organic osmolytes. Biology of Reproduction 82 769-777. (doi:10.1095/biolreprod.109.081646)

Riley JK, Carayannopoulos MO, Wyman AH, Chi M, Ratajczak CK \& Moley KH 2005 The PI3K/Akt pathway is present and functional in the preimplantation mouse embryo. Developmental Biology 284 377-386. (doi:10.1016/j.ydbio.2005.05.033)

Rizos D, Fair T, Papadopoulos S, Boland MP \& Lonergan P 2002a Developmental, qualitative, and ultrastructural differences between 
ovine and bovine embryos produced in vivo or in vitro. Molecular Reproduction and Development 62 320-327. (doi:10.1002/mrd.10138)

Rizos D, Lonergan P, Boland MP, Arroyo-Garcia R, Pintado B, de la Fuente J \& Gutierrez-Adan A 2002b Analysis of differential messenger RNA expression between bovine blastocysts produced in different culture systems: implications for blastocyst quality. Biology of Reproduction 66 589-595. (doi:10.1095/biolreprod66.3.589)

Rizos D, Gutierrez-Adan A, Perez-Garnelo S, De La Fuente J, Boland MP \& Lonergan P 2003 Bovine embryo culture in the presence or absence of serum: implications for blastocyst development, cryotolerance, and messenger RNA expression. Biology of Reproduction 68 236-243. (doi:10.1095/biolreprod.102.007799)

Rodriguez-Alvarez L, Sharbati J, Sharbati S, Cox JF, Einspanier R \& Castro FO 2010 Differential gene expression in bovine elongated (Day 17) embryos produced by somatic cell nucleus transfer and in vitro fertilization. Theriogenology 74 45-59. (doi:10.1016/j.theriogenology.2009.12.018)

Romek M, Gajda B, Krzysztofowicz E \& Smorag Z 2009 Lipid content of non-cultured and cultured pig embryo. Reproduction in Domestic Animals 44 24-32. (doi:10.1111/j.1439-0531.2007.00984.x)

Sakatani M, Yamanaka K, Kobayashi S \& Takahashi M 2008 Heat shockderived reactive oxygen species induce embryonic mortality in in vitro early stage bovine embryos. Journal of Reproduction and Development 54 496-501. (doi:10.1262/jrd.20017)

Sakatani M, Alvarez NV, Takahashi M \& Hansen PJ 2012 Consequences of physiological heat shock beginning at the zygote stage on embryonic development and expression of stress response genes in cattle. Journal of Dairy Science 95 3080-3091. (doi:10.3168/jds.2011-4986)

Sakatani M, Bonilla L, Dobbs KB, Block J, Ozawa M, Shanker S, Yao J \& Hansen PJ 2013 Changes in the transcriptome of morula-stage bovine embryos caused by heat shock: relationship to developmental acquisition of thermotolerance. Reproductive Biology and Endocrinology 113. (doi:10.1186/1477-7827-11-3)

Salilew-Wondim D, Fournier E, Hoelker M, Saeed-Zidane M, Tholen E, Looft C, Neuhoff C, Besenfelder U, Havlicek V, Rings F et al. 2015 Genome-wide DNA methylation patterns of bovine blastocysts developed in vivo from embryos completed different stages of development in vitro. PLOS ONE 10 e0140467. (doi:10.1371/journal.pone.0140467)

Salmen JJ, Skufca F, Matt A, Gushansky G, Mason A \& Gardiner CS 2005 Role of glutathione in reproductive tract secretions on mouse preimplantation embryo development. Biology of Reproduction 73 308-314. (doi:10.1095/biolreprod.104.038307)

San Martin S, Soto-Suazo M, De Oliveira SF, Aplin JD, Abrahamsohn P \& Zorn TM 2003 Small leucine-rich proteoglycans (SLRPs) in uterine tissues during pregnancy in mice. Reproduction 125 585-595. (doi:10.1530/ rep.0.1250585)

Scantland S, Tessaro I, Macabelli CH, Macaulay AD, Cagnone G, Fournier E, Luciano AM \& Robert C 2014 The adenosine salvage pathway as an alternative to mitochondrial production of ATP in maturing mammalian oocytes. Biology of Reproduction 91 75. (doi:10.1095/ biolreprod.114.120931)

Schini SA \& Bavister BD 1988 Two-cell block to development of cultured hamster embryos is caused by phosphate and glucose. Biology of Reproduction 39 1183-1192. (doi:10.1095/biolreprod39.5.1183)

Scott L \& Whittingham DG 2002 Role of facilitative glucose uptake in the glucose-inorganic phosphate-mediated retardation and inhibition of development in different strains of mouse embryos. Reproduction 123 691-700. (doi:10.1530/rep.0.1230691)

Seli E, Robert C \& Sirard MA 2010 OMICS in assisted reproduction: possibilities and pitfalls. Molecular Human Reproduction 16 513-530. (doi:10.1093/molehr/gaq041)

Seshagiri PB \& Bavister BD 1991 Glucose and phosphate inhibit respiration and oxidative metabolism in cultured hamster eight-cell embryos: evidence for the "crabtree effect". Molecular Reproduction and Development 30 105-111. (doi:10.1002/mrd.1080300206)

Shankar K, Zhong Y, Kang P, Lau F, Blackburn ML, Chen JR, Borengasser SJ, Ronis MJ \& Badger TM 2011 Maternal obesity promotes a proinflammatory signature in rat uterus and blastocyst. Endocrinology 152 4158-4170. (doi:10.1210/en.2010-1078)

Silva CF, Sartorelli ES, Castilho AC, Satrapa RA, Puelker RZ, Razza EM, Ticianelli JS, Eduardo HP, Loureiro B \& Barros CM 2013 Effects of heat stress on development, quality and survival of Bos indicus and Bos taurus embryos produced in vitro. Theriogenology 79 351-357. (doi:10.1016/j. theriogenology.2012.10.003)
Sistigu A, Yamazaki T, Vacchelli E, Chaba K, Enot DP, Adam J, Vitale I, Goubar A, Baracco EE, Remedios C et al. 2014 Cancer cell-autonomous contribution of type I interferon signaling to the efficacy of chemotherapy. Nature Medicine 20 1301-1309. (doi:10.1038/nm.3708)

Smith SL, Everts RE, Sung LY, Du F, Page RL, Henderson B, Rodriguez-Zas SL, Nedambale TL, Renard JP, Lewin HA et al. 2009 Gene expression profiling of single bovine embryos uncovers significant effects of in vitro maturation, fertilization and culture. Molecular Reproduction and Development 76 38-47. (doi:10.1002/mrd.20927)

Spielmann H, Jacob-Mueller U, Schulz P \& Schimmel A 1984 Changes of the adenine ribonucleotide content during preimplantation development of mouse embryos in vivo and in vitro. Journal of Reproduction and Fertility 71 467-473. (doi:10.1530/jrf.0.0710467)

Stamatkin CW, Roussev RG, Stout M, Coulam CB, Triche E, Godke RA \& Barnea ER 2011 Preimplantation factor negates embryo toxicity and promotes embryo development in culture. Reproductive Biomedicine Online 23 517-524. (doi:10.1016/j.rbmo.2011.06.009)

Steegers-Theunissen RP, Twigt J, Pestinger V \& Sinclair KD 2013 The periconceptional period, reproduction and long-term health of offspring: the importance of one-carbon metabolism. Human Reproduction Update 19 640-655. (doi:10.1093/humupd/dmt041)

Stigliani S, Anserini P, Venturini PL \& Scaruffi P 2013 Mitochondrial DNA content in embryo culture medium is significantly associated with human embryo fragmentation. Human Reproduction 28 2652-2660. (doi:10.1093/humrep/det314)

Stigliani S, Persico L, Lagazio C, Anserini P, Venturini PL \& Scaruffi P 2014 Mitochondrial DNA in Day 3 embryo culture medium is a novel, noninvasive biomarker of blastocyst potential and implantation outcome. Molecular Human Reproduction 20 1238-1246. (doi:10.1093/molehr/ gau086)

Stover SK, Gushansky GA, Salmen JJ \& Gardiner CS 2000 Regulation of gamma-glutamate-cysteine ligase expression by oxidative stress in the mouse preimplantation embryo. Toxicology and Applied Pharmacology 168 153-159. (doi:10.1006/taap.2000.9030)

Sudano MJ, Caixeta ES, Paschoal DM, Martins A, Machado R, Buratini J \& Landim-Alvarenga FD 2014 Cryotolerance and global gene-expression patterns of Bos taurus indicus and Bos taurus taurus in vitro- and in vivo-produced blastocysts. Reproduction Fertility and Development 26 1129-1141. (doi:10.1071/RD13099)

Suh YS, Yu J, Kim BC, Choi B, Han TS, Ahn HS, Kong SH, Lee HJ, Kim WH \& Yang HK 2015 Overexpression of plasminogen activator inhibitor-1 in advanced gastric cancer with aggressive lymph node metastasis. Cancer Research and Treatment 47 718-726. (doi:10.4143/crt.2014.064)

Summers MC \& Biggers JD 2003 Chemically defined media and the culture of mammalian preimplantation embryos: historical perspective and current issues. Human Reproduction Update 9 557-582. (doi:10.1093/ humupd/dmg039)

Swain JE, Bormann CL, Clark SG, Walters EM, Wheeler MB \& Krisher RL 2002 Use of energy substrates by various stage preimplantation pig embryos produced in vivo and in vitro. Reproduction 123 253-260. (doi:10.1530/rep.0.1230253)

Takahashi M, Nagai T, Hamano S, Kuwayama M, Okamura N \& Okano A 1993 Effect of thiol compounds on in vitro development and intracellular glutathione content of bovine embryos. Biology of Reproduction 49 228-232. (doi:10.1095/biolreprod49.2.228)

Takizawa F, Mizutani S, Ogawa Y \& Sawada N 2013 Glucose-independent persistence of PAI-1 gene expression and $\mathrm{H} 3 \mathrm{~K} 4$ tri-methylation in type 1 diabetic mouse endothelium: implication in metabolic memory. Biochemical and Biophysical Research Communications 433 66-72. (doi:10.1016/j.bbrc.2013.02.064)

Taylor TH, Gitlin SA, Patrick JL, Crain JL, Wilson JM \& Griffin DK 2014 The origin, mechanisms, incidence and clinical consequences of chromosomal mosaicism in humans. Human Reproduction Update 20 571-581. (doi:10.1093/humupd/dmu016)

Thompson JG, Simpson AC, Pugh PA, Wright RW Jr \& Tervit HR 1991 Glucose utilization by sheep embryos derived in vivo and in vitro. Reproduction Fertility and Development 3 571-576. (doi:10.1071/ RD9910571)

Thompson JG, McNaughton C, Gasparrini B, McGowan LT \& Tervit HR 2000 Effect of inhibitors and uncouplers of oxidative phosphorylation during compaction and blastulation of bovine embryos cultured in vitro. Journal of Reproduction and Fertility 118 47-55. (doi:10.1530/ reprod/118.1.47) 
Toyama EQ, Herzig S, Courchet J, Lewis TL Jr, Loson OC, Hellberg K, Young NP, Chen H, Polleux F, Chan DC et al. 2016 Metabolism. AMP-activated protein kinase mediates mitochondrial fission in response to energy stress. Science 351 275-281. (doi:10.1126/ science.aab4138)

Treff NR, SuJ, Taylor D \& Scott RT Jr 2011 Telomere DNA deficiency is associated with development of human embryonic aneuploidy. PLOS Genetics 7 e1002161. (doi:10.1371/journal.pgen.1002161)

Trimarchi JR, Liu L, Porterfield DM, Smith PJ \& Keefe DL 2000 Oxidative phosphorylation-dependent and -independent oxygen consumption by individual preimplantation mouse embryos. Biology of Reproduction 62 1866-1874. (doi:10.1095/biolreprod62.6.1866)

Truong TT, Soh YM \& Gardner DK 2016 Antioxidants improve mouse preimplantation embryo development and viability. Human Reproduction 31 1445-1454. (doi:10.1093/humrep/dew098)

Van Blerkom J, Davis PW \& Lee J 1995 ATP content of human oocytes and developmental potential and outcome after in-vitro fertilization and embryo transfer. Human Reproduction 10 415-424.

Van Hoeck V, Rizos D, Gutierrez-Adan A, Pintelon I, Jorssen E, Dufort I, Sirard MA, Verlaet A, Hermans N, Bols PE et al. 2015 Interaction between differential gene expression profile and phenotype in bovine blastocysts originating from oocytes exposed to elevated non-esterified fatty acid concentrations. Reproduction Fertility and Development 27 372-384. (doi:10.1071/RD13263)

Van Sinderen M, Menkhorst E, Winship A, Cuman C \& Dimitriadis E 2013 Preimplantation human blastocyst-endometrial interactions: the role of inflammatory mediators. American Journal of Reproductive Immunology 69 427-440. (doi:10.1111/aji.12038)

van Soom A, Ysebaert MT \& de Kruif A 1997 Relationship between timing of development, morula morphology, and cell allocation to inner cell mass and trophectoderm in in vitro-produced bovine embryos. Molecular Reproduction and Development 47 47-56. (doi:10.1002/ (SICI)1098-2795(199705)47:1 \&lt;47::AID-MRD7\&gt;3.0.CO;2-Q)

Van Soom A, Yuan YQ, Peelman LJ, de Matos DG, Dewulf J, Laevens H \& de Kruif A 2002 Prevalence of apoptosis and inner cell allocation in bovine embryos cultured under different oxygen tensions with or without cysteine addition. Theriogenology 57 1453-1465. (doi:10.1016/ S0093-691X(01)00726-9)

Vander Heiden MG, Cantley LC \& Thompson CB 2009 Understanding the Warburg effect: the metabolic requirements of cell proliferation. Science 324 1029-1033. (doi:10.1126/science.1160809)

Van Winkle LJ \& Dickinson HR 1995 Differences in amino acid content of preimplantation mouse embryos that develop in vitro versus in vivo: in vitro effects of five amino acids that are abundant in oviductal secretions. Biology of Reproduction 52 96-104.

Vazquez-Diez C, Yamagata K, Trivedi S, Haverfield J \& FitzHarris G 2016 Micronucleus formation causes perpetual unilateral chromosome inheritance in mouse embryos. PNAS 113 626-631. (doi:10.1073/ pnas.1517628112)

Wale PL \& Gardner DK 2013a Oxygen affects the ability of mouse blastocysts to regulate ammonium. Biology of Reproduction 8975 . (doi:10.1095/biolreprod.113.109256)

Wale PL \& Gardner DK 2013b Oxygen regulates amino acid turnover and carbohydrate uptake during the preimplantation period of mouse embryo development. Biology of Reproduction 87 24, 21-28.

Wale PL \& Gardner DK 2015 The effects of chemical and physical factors on mammalian embryo culture and their importance for the practice of assisted human reproduction. Human Reproduction Update 22 2-22. (doi:10.1093/humupd/dmv034)

Wallace R 2009 Metabolic constraints on the eukaryotic transition. Origins of Life and Evolution of Biospheres 39 165-176. (doi:10.1007/s11084009-9157-6)

Wallace DC \& Fan W 2010 Energetics, epigenetics, mitochondrial genetics. Mitochondrion 10 12-31. (doi:10.1016/j.mito.2009.09.006)

Wang H, Maechler P, Antinozzi PA, Hagenfeldt KA \& Wollheim CB 2000 Hepatocyte nuclear factor 4alpha regulates the expression of pancreatic beta-cell genes implicated in glucose metabolism and nutrient-induced insulin secretion. Journal of Biological Chemistry 275 35953-35959. (doi:10.1074/jbc.M006612200)

Wang FW, Zhang YM, Wang Z, Liu SM, Wang LY, Zhang XL, Jia DY, Hao AJ \& Wu YL 2013a Calcitonin promotes mouse pre-implantation development: involvement of calcium mobilization and P38 mitogen-activated protein kinase activation. Reproduction in Domestic Animals 48 382-389. (doi:10.1111/rda.12000)

Wang Z, Cao R, Taylor K, Briley A, Caldwell C \& Cheng J 2013b The properties of genome conformation and spatial gene interaction and regulation networks of normal and malignant human cell types. PLoS ONE 8 e58793. (doi:10.1371/journal.pone.0058793)

Wentzel P, Wentzel CR, Gareskog MB \& Eriksson UJ 2001 Induction of embryonic dysmorphogenesis by high glucose concentration, disturbed inositol metabolism, and inhibited protein kinase $\mathrm{C}$ activity. Teratology 63 193-201. (doi:10.1002/tera.1034)

Wentzel P, Ejdesjo A \& Eriksson UJ 2003 Maternal diabetes in vivo and high glucose in vitro diminish GAPDH activity in rat embryos. Diabetes 52 1222-1228. (doi:10.2337/diabetes.52.5.1222)

Wong SL, Wu LL, Robker RL, Thompson JG \& McDowall ML 2015 Hyperglycaemia and lipid differentially impair mouse oocyte developmental competence. Reproduction Fertility and Development 27 583-592. (doi:10.1071/RD14328)

Wrenzycki C, Herrmann D, Carnwath JW \& Niemann H 1996 Expression of the gap junction gene connexin43 (Cx43) in preimplantation bovine embryos derived in vitro or in vivo. Journal of Reproduction and Fertility 108 17-24. (doi:10.1530/jrf.0.1080017)

Wynne F, Ball M, McLellan AS, Dockery P, Zimmermann W \& Moore T 2006 Mouse pregnancy-specific glycoproteins: tissue-specific expression and evidence of association with maternal vasculature. Reproduction 131 721-732. (doi:10.1530/rep.1.00869)

Xie Y, Zhong W, Wang Y, Trostinskaia A, Wang F, Puscheck EE \& Rappolee DA 2007 Using hyperosmolar stress to measure biologic and stress-activated protein kinase responses in preimplantation embryos. Molecular Human Reproduction 13 473-481. (doi:10.1093/molehr/ gam027)

Xu J \& Sinclair KD 2015 One-carbon metabolism and epigenetic regulation of embryo development. Reproduction Fertility and Development 27 667-676. (doi:10.1071/RD14377)

Yadav A, Singh KP, Singh MK, Saini N, Palta P, Manik RS, Singla SK, Upadhyay RC \& Chauhan MS 2013 Effect of physiologically relevant heat shock on development, apoptosis and expression of some genes in buffalo (Bubalus bubalis) embryos produced in vitro. Reproduction in Domestic Animals 48 858-865. (doi:10.1111/rda.12175)

Yang HW, Hwang KJ, Kwon HC, Kim HS, Choi KW \& Oh KS 1998 Detection of reactive oxygen species (ROS) and apoptosis in human fragmented embryos. Human Reproduction 13 998-1002. (doi:10.1093/ humrep/13.4.998)

Yang H, Taylor HS, Lei C, Cheng C \& Zhang W 2011 Hormonal regulation of galectin 3 in trophoblasts and its effects on endometrium. Reproductive Sciences 18 1118-1127. (doi:10.1177/1933719111407212)

Yang W \& Lu Z 2013 Nuclear PKM2 regulates the Warburg effect. Cell Cycle 12 3154-3158.

Yang W, Zheng Y, Xia Y, Ji H, Chen X, Guo F, Lyssiotis CA, Aldape K, Cantley LC \& Lu Z 2013 ERK1/2-dependent phosphorylation and nuclear translocation of PKM2 promotes the Warburg effect. Nature Cell Biology 14 1295-1304. (doi:10.1038/ncb2629)

Zheng P, Vassena R \& Latham KE 2007 Effects of in vitro oocyte maturation and embryo culture on the expression of glucose transporters, glucose metabolism and insulin signaling genes in rhesus monkey oocytes and preimplantation embryos. Molecular Human Reproduction 13 361-371. (doi:10.1093/molehr/gam014)

Zhou W, Choi M, Margineantu D, Margaretha L, Hesson J, Cavanaugh C, Blau CA, Horwitz MS, Hockenbery D, Ware C et al. 2012 HIF1alpha induced switch from bivalent to exclusively glycolytic metabolism during ESC-to-EpiSC/hESC transition. EMBO Journal 31 2103-2116. (doi:10.1038/emboj.2012.71)

Zolnierowicz S, Scislowski PW, Swierczynski J \& Zelewski L 1984 Acetoacetate utilization by human placental mitochondria. Placenta 5 271-276. (doi:10.1016/S0143-4004(84)80037-5)

Received 19 July 2016

First decision 4 August 2016

Revised manuscript received 29 August 2016

Accepted 5 September 2016 